\title{
Agroindustrial Wastes as Substrates for Microbial Enzymes Production and Source of Sugar for Bioethanol Production
}

\author{
Daniela Alonso Bocchini Martins ${ }^{1}$, Heloiza Ferreira Alves do Prado ${ }^{2}$, \\ Rodrigo Simões Ribeiro Leite ${ }^{3}$, Henrique Ferreira ${ }^{4}$, Márcia Maria de Souza \\ Moretti $^{5}$, Roberto da Silva ${ }^{5}$ and Eleni Gomes ${ }^{5}$ \\ ${ }^{1}$ Univ. Estadual Paulista - UNESP, IQ - Araraquara Campus \\ ${ }^{2}$ Univ. Estadual Paulista - UNESP, FE - Ilha Solteira Campus \\ ${ }^{3}$ Federal University of Grande Dourados - UFGD \\ ${ }^{4}$ Univ. Estadual Paulista - UNESP, FCF - Araraquara Campus \\ ${ }^{5}$ Univ. Estadual Paulista - UNESP, IBILCE - São José do Rio Preto Campus \\ Brazil
}

\section{Introduction}

Environmental issues and concerns aimed at reducing the ambient pollution have boosted the search for "clean Technologies" to be used in the production of commodities of importance to chemical, energy and food industries. This practice makes use of alternative materials, requires less energy, and diminishes pollutants in industrial effluents, as well as being more economically advantageous due to its reduced costs. Considering this scenario, the use of residues from agroindustrial, forestry and urban sources in bioprocesses has aroused the interest of the scientific community lately. The utilization of such materials as substrates for microbial cultivation intended to produce cellular proteins, organic acids, mushrooms, biologically important secondary metabolites, enzymes, prebiotic oligosaccharides, and as sources of fermentable sugars in the second generation ethanol production has been reported (Sánchez, 2009). Notably, the microbial enzymes can be the products themselves as well as tools in these bioprocesses. Agroindustrial wastes are valuable sources of lignocellulosic materials. The lignocellulose is the main structural constituent of plants and represents the primary source of renewable organic matter on earth. It can be found at the cellular wall, and is composed of cellulose, hemicellulose and lignin, plus organic acids, salts and minerals (Pandey et al., 2000; Hamelinck et al., 2005). Therefore, such residues are superior substrates for the growth of filamentous fungi, which produce cellulolytic, hemicellulolytic and ligninolytic enzymes by solid state fermentation (SSF). These fungi are considered the better adapted organisms for SSF, since their hyphae can grow on the surface of particles and are also able to penetrate through the inter particle spaces, and then, to colonize it (Santos et al., 2004). Filamentous fungi are the most distinguished producers of enzymes involved in the degradation of lignocellulosic material, and the search for new strains displaying high potential of enzyme production is of great 
biotechnological importance. Several agroindustrial wastes are commonly used for this purpose, such as sugarcane bagasse, wheat bran, corn cob and straw, rice straw and husk, soy bran, barley and coffee husk (Sanchéz, 2009). Microbial cellulases, xylanases and ligninases are enzymes with potential application in several biotechnology processes. For decades, such enzymes have been used in the textile, detergent, pulp and paper, food for animals and humans (Bocchini et al., 2003; Kumar et al, 2004;Maicas \& Mateo, 2005; Graminha et al., 2008; Hebeish et al., 2009). Recently, research has been focused on the potential use of these enzymes for the degradation of lignocellulosic materials, aiming at the releasing of fermentable sugars that can be converted to second generation ethanol by the action of fermentative microorganisms (Buaban et al., 2010; Talebnia et al, 2010). Among the enzymatically saccharified lignocellulosic wastes intended for the production of ethanol one can cite rice straw, wheat bran, wheat straw, sawdust, rice husk, corn straw and sugarcane bagasse, being the later greatly abundant in Brazil (Binod et al., 2010; Martín et al., 2007). Bearing this in mind, research has been focused on the development of new technologies capable of making the sugar available from bagasse, in order to supply the internal market and also to be exported (Cerqueira Leite et al., 2009). The intimate chemical and physical association between lignin and polysaccharides from the plant cell wall makes the enzymatic degradation of the carbohydrate portion difficult, and consequently the extraction of fermentable sugars, since this phenylpropanoid polymer is not easily degraded biologically. Furthermore, the crystalline structure of cellulose prevents the action of microbial enzymes (Gould, 1984). In order to facilitate the enzymes access to the polysaccharides, especially the cellulose, several pretreatments of the lignocellulosic materials have been proposed, with the intention of disorganizing the plant cell wall structure and lignin removal (Krishna, Chowdary, 2005). In this chapter, we will approach the application of lignocellulosic wastes as substrates for the growth of microorganisms able to produce enzymes such as cellulases, hemicellulases and ligninases, and as sources of fermentable sugars in the production of second generation ethanol, via enzymatic hydrolysis. It will be emphasized the composition of the main residues, the prominent microorganisms, their enzymes and mechanisms of action involved with lignocellulose degradation, SSF characteristics, pretreatment methods and enzymatic hydrolysis of lignocellulosic material, as well as the strategies that have been explored for second generation ethanol production.

\section{Lignocellulose}

Lignocellulose is the name given to the material present in the cell wall of higher terrestrial plants, made up of microfibriles of cellulose embebed in an amorphous matrix of hemicellulose and lignin (Fig. 1) (Martínez et al., 2009).

These three types of polymers are strongly bonded to one another and represent more than $90 \%$ of the vegetable cell's dry weight. The quantity of each polymer varies according to the species, harvest season and, also, throughout different parts of the same plant. In general, softwoods (gimnosperms such as pine and cedrus) have higher lignin content than hardwoods (angiosperm such as eucalyptus and oak). Hemicellulose content, however, is higher in gramineous plants. In average, lignocellulose consists of $45 \%$ of cellulose, $30 \%$ of hemicellulose and 25\% of lignin (Glazer \& Nikaido, 2007). Lignocellulosic materials also include agricultural residues (straws, stover, stalks, cobs, bagasses, shells), industrial 
residues (sawdust and paper mill discards-, food industry residues), urban solid wastes e domestic wastes (garbage and sewage) (Mtui, 2009).

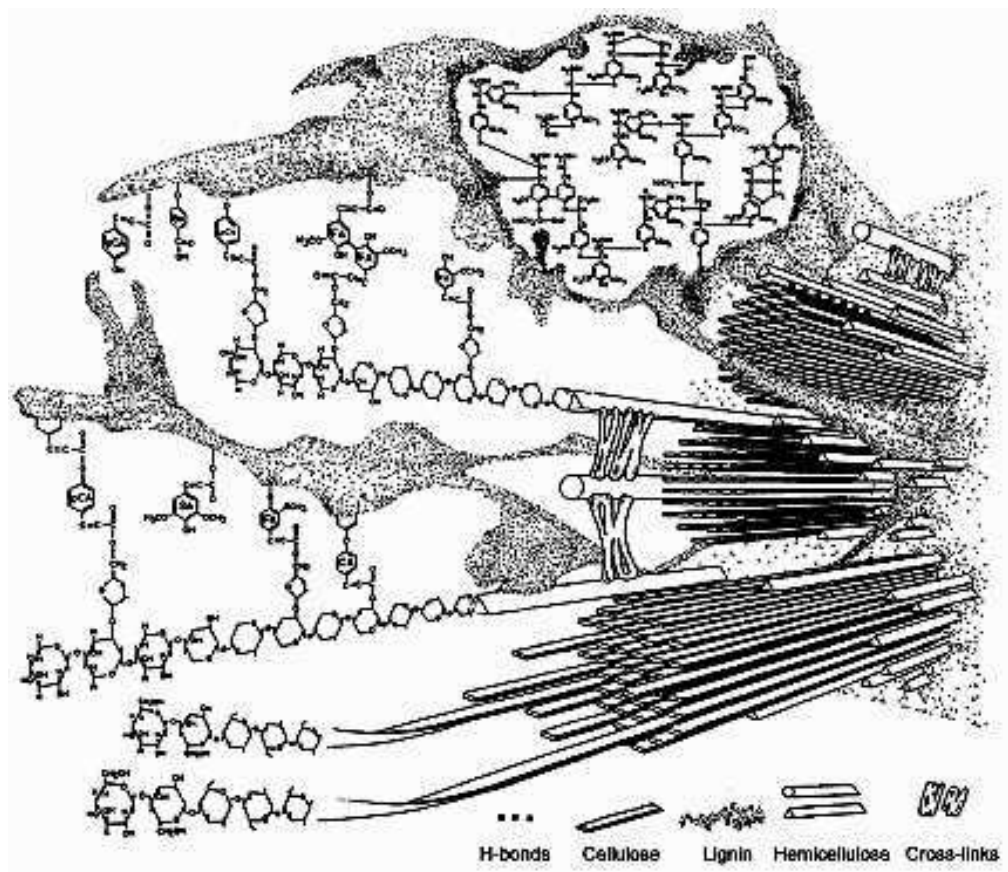

Fig. 1. Scheme of secondary plant cell wall. CA: $p$-coumaric acid; FA: ferulic acid; SA: sinapic acid. Source: Bidlack et al, 1992.

Lignocellulose is the world's main source of renewable organic matter and the chemical properties of its components make it a material of great biotechnological value. Therefore, a few years ago, the concept of lignocellulose biorefinery emerged, which has received growing attention due to the potential of conversion of this material into many high added value products such as chemical compounds, fermentation substrates, feedstock and biofuels (Ragauskas et al., 2006; Demirbas, 2008).

The accentuated growth of the world's consumption of energy originating from fossil resources has aggravated the problem of atmospheric pollution by the release of gases related to the greenhouse effect. For this reason, besides the high cost of petroleum and the eminent depletion of these resources in a few decades from now, the obtainment of fuels from renewable sources, such as lignocellulosic biomass, has aroused great interest in the last years. Currently, it is believed that ethanol, as the main form of bioenergy, is the best alternative to the use of fossil fuels (Wang et al., 2011).

Inside this context, new technologies have been developed for the efficient obtainment of fuels from lignocellulosic bimass and developed and developing Countries have been focusing efforts in researches aimed at obtaining the so called biofuels, such as bioethanol and biodiesel, as well as their introduction and prevalence in the market (Hamelinck et al., 2005; Prasad et al., 2007). 


\subsection{Cellulose}

Cellulose is the most abundant organic compound on Earth and the main constituent of plant cell walls. It consists of linear chains of aproximately 8,000 to 12,000 residues of Dglucose linked by $\beta-1,4$ bonds (Timell, 1967; Aro et al., 2005). Cellulose chains exhibit a flat structure, stabilized by internal hydrogen bonds (Fig. 2). All alternate glucose residues in the same cellulose chain are rotated $180^{\circ}$. One glucose residue is the monomeric unit of cellulose and the dimer, cellobiose, is the chain's repetitive structural unit (Brown Jr et al., 1996). Cellulose chain is polarized, once there is a nonreducing group at one of its end and, at the opposite end there is a reducing group. New glucose residues, originating from UDPglucose, are added to the nonreducing end during polymer synthesis (Koyama et al., 1997). Parallel cellulose chains interact, through hydrogen bonds and van der Waals forces, resulting in microfibriles, which are very extensive and crystaline aggregates (Glazer \& Nikaido, 2007; Somerville et al., 2004).

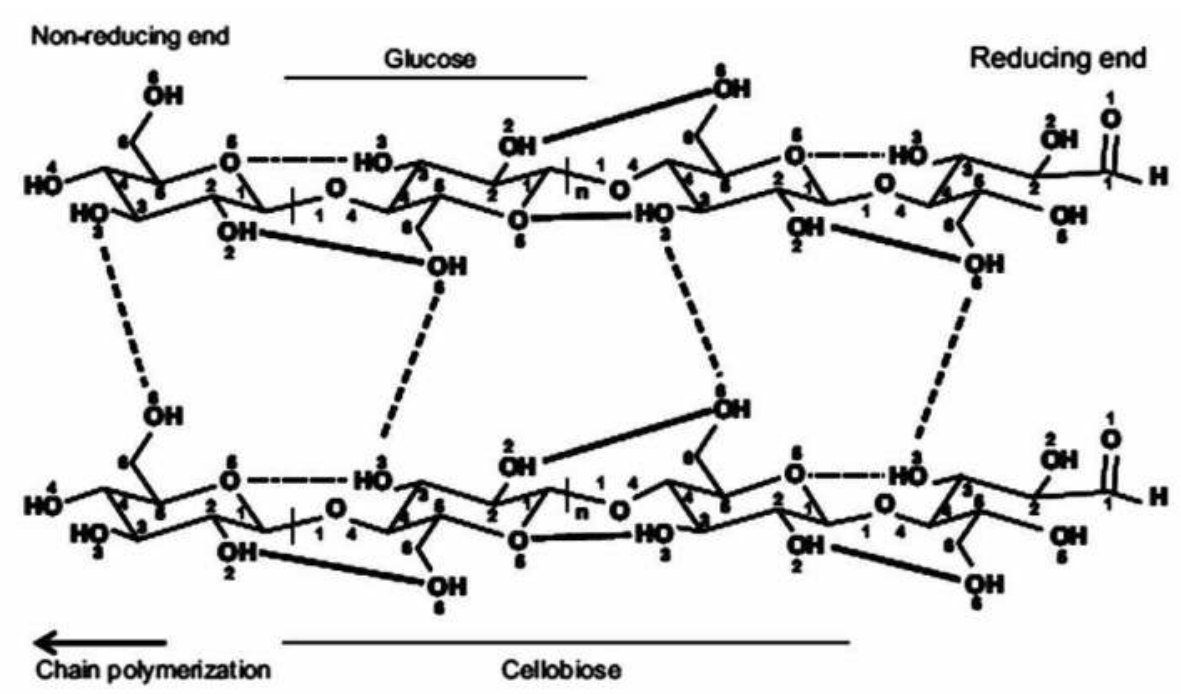

Fig. 2. Representative structure of cellulose chains. Dotted and solid lines: inter and intra chain hydrogen bonds, respectively. Source: Festucci-Buselli et al., 2007.

The microfibriles are made up of aproximately 30-36 glucan chains, exhibit a 2-10 nm diameter and are cross-linked by other components of the cell wall, such as the xiloglucans. (Arantes \& Saddler, 2010). The cellulose microfibriles networks are called macrofibrils, which are organized in lamellas to form the fibrous structure of the many layers of plant cell wall (Fig. 3) (Glazer \& Nikaido, 2007).

In cellulose fibers, crystaline and amorphous regions alternate. The crystaline regions are very cohesive, with rigid structure, formed by the parallel configuration of linear chains, which results in the formation of intermolecular hydrogen bonds, contributing to cellulose's insolubility and low reactivity, at the same time making it more resistant to acid hydrolysis, making water entrance difficult and modifying fiber elasticity. The amorphous regions are formed by cellulose chains with weaker organization, being more accessible to enzymes and susceptible to hydrolysis (Bobbio \& Bobbio, 2003; Nelson \& Cox, 2006). 


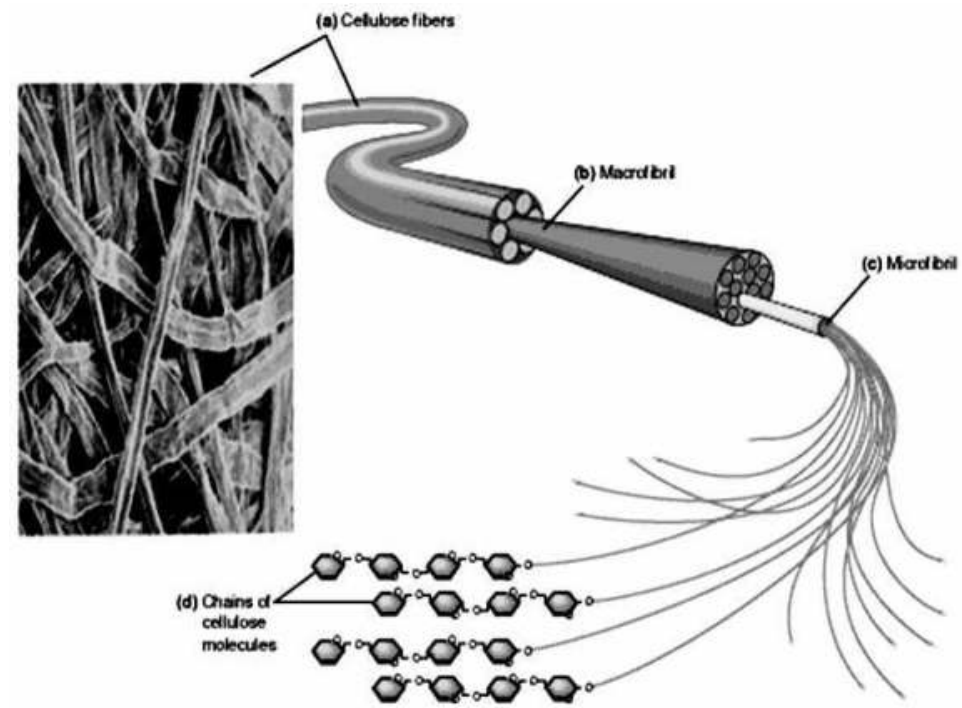

Fig. 3. Representative scheme of cellulose fiber Available from http:// nutrition.jbpub.com/resources/chemistryreview9.cfm.

\subsection{Hemicellulose}

Hemicellulose is the second group of most abundant polyssacharide in plant cell wall and, differently from cellulose, it is made up of non crystaline heteropolyssacharides (Aspinall, 1959).

Schulze (1891) initialy classified hemicellulose as the polyssacharide fraction of plant cell wall easily hydrolized, an imprecise classification which was used for a long time. The group also defined as polyssacharides present in plant cell wall and intercellularly (in the middle lamella), extracted from higher terrestrial plant tissues through alkaline treatment or, yet, as certain carbohydrates of cereal endosperms, which are non starch polyssacharides that are described as cereal gum or pentosans (Timell, 1965; Wilkie, 1979).

Afterwards, hemicellulose classification was redefined, based on the chemical properties of its components, including only cell wall polyssacharides non covalently bonded to cellulose made up by $\beta-(1,4)$-linked pyranosyl residues that have the $O-4$ in the equatorial position. Such characteristics result in a conformation that is very similar to cellulose (cellulose-like conformation) and cause a tendency to hydrogen-bond to cellulose chains (O’Neill \& York, 2003).

In a general way, the hemicellulose fraction makes up 15 to $35 \%$ of plant biomass, representing a great renewable source of biopolymers which may contain pentoses ( $\beta$-D-xylose, $\alpha-\mathrm{L}$ arabinose), hexoses ( $\beta$-D-mannose, $\beta$-D-glucose, $\alpha$-D-galactose) and/or uronic acids ( $\alpha$-Dglucuronic, $\alpha$-D-4-O-methylgalacturonic and $\alpha$-D-galacturonic acids). Other sugars such as $\alpha$ L-rhamnose and $\alpha$-L-fucose may also be present in small amounts and the hydroxyl groups of sugars can be partially substituted with acetyl groups (Gírio et al., 2010). Therefore, hemicllulose classification depends on the type of monomer constituent and these may be called xyloglucans, xylans (xyloglycans), mannans (mannoglycans) and $\beta-(1 \rightarrow 3,1 \rightarrow 4)$-glucans (mixed-linkage $\beta$-glucans). Galactans, arabinans and arabinogalactans are also many times 
included in the hemicellulose group, however do not share the equatorial $\beta-(1 \rightarrow 4)$-linked backbone structure (Scheller \& Ulvskov, 2010). Its form and structure depend on where they are present, being in woods or fruits cell walls (Dey \& Brinson, 1984).

Most of the hemicelluloses are relatively small molecules, containing 70 to 200 residues of monossacharides, being hardwood hemicellulose the largest molecules with 150 to 200 units (Coughlan, 1992).

Hemicelluloses associate to cellulose by physical intermixing and hydrogen bonds, and to lignina e pectin, by covalent bonds (Freudenberg, 1965).

\subsubsection{Xylans}

Xylans, the most relevant components of hemicellulose, constitute the secong group of polyssacharides most abundant in nature, contributing to aproximately one third of all the renewable organic carbon on Earth (Prade, 1995). Xylans constitute about $20-30 \%$ of the biomass of hardwoods and herbaceous plants. In some tissues of grasses and cereals xylans can account up to 50\% (Ebringerová et al., 2005).

Xylans are mainly situated in the secondary cell wall of plants (Timell, 1965), in close contact to cellulose through strong interactions established by hydrogen bonds and van der walls forces. They may also be present in the primary cell wall, in particular in monocotyledoneans (Wong et al., 1988). Their molecules are oriented parallel to cellulose chains, in the cell wall matrix, and are located between cellulose microfibriles (Northcote, 1972). Xylan, covalently bonded to lignin and non covalentely bonded to cellulose, exhibits important role in maintaining cellulose integrity in situ, protecting the fibers against the action of cellulases (Beg et al., 2001; Uffen, 1997).

Xylans of all higher plants are heteropolysaccharides with a backbone of $\beta-(1 \rightarrow 4)$ linked xylopryranose units, usually substituted with sugar units and O-acetyl groups (Stephen, 1983). Exception to this pattern have been isolated from the seeds of Plantago species (Sandhu et al., 1981; Samuelsen et al., 1999) The occurrence of homoxylans in higher plants is rather rare, being isolated from esparto grass (Chanda et al., 1950), tabaco caule (Eda et al., 1976), guar seeds (Montgomery et al., 1956) and from some marine algea (Barry \& Dillon, 1940; Nunn et al., 1973).

Methylglucuronoxylans (MXG) (O-acetil-4-O-metilglucuronoxylans) are dominating in the secondary walls of hardwoods (dicots such as eucalipto e carvalho) having single side chains of $\alpha$-D-glucuronic acid (GA) and/or its 4-O-methyl derivative (MeGA) attached at position 2 of the xylopyranose monomer units (Ebringerová \& Heinze, 2005). The content of acetyl groups varies in the range $3-13 \%$ and is responsible for xylan's partial solubility in water (Sunna \& Antranikian, 1997).

Arabinoglucuronoxylan (AGX) (arabino-4-O- methylglucuronoxylans) are the major components of non-woody materials (e.g., agricultural crops, grasses) and a minor component (5-10\% of dry mass) for softwoods (ex gimnosperms such as pine and cedrus). They contain single side chains of 2-Olinked $\alpha$-D-glucopyranosyl uronic acid unit (GA) and/or its 4-Omethyl derivative (MeGA) and 3-linked $\alpha$-L-arabinofuranosyl unit (Timell, 1965; Sunna \& Antranikian, 1997).

Into the cell walls polysaccharides of forage and grasses, ferulic acid residues are introduced via an ester linkage between their carboxylic acid group and the primary alcohol on the C5 carbon of the arabinose side chain of arabinoxylans (Hartley, 1973) (Fig. 4), but can also be covalently linked to lignin monomers via an ether linkage (Kondo et al., 1990). So, ferulic acid participates with lignin monomers in oxidative coupling pathways to generate ferulate- 
polysaccharide-lignin complexes that cross-link the cell wall (Buanafina, 2009). Esters of pcoumaric acid are also abundant in grass cell walls, but it is not clear if they can be attached directly to the xylans, and they may be primarily associated with lignin (Hatfield et al., 2008).

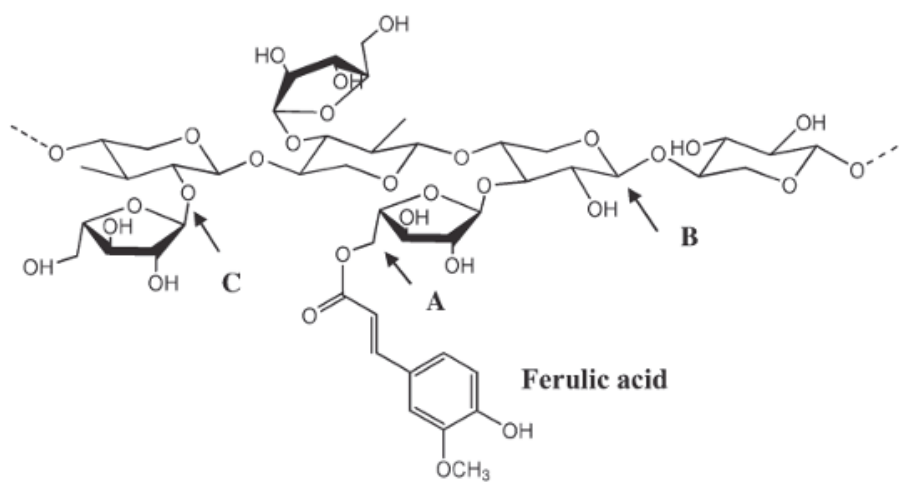

Fig. 4. Structure of ferulic acid esterified to arabinose units of arabinoxylan. A: ferulic acid linked to O-5 of arabinose chain of arabinoxylan; B: $\beta-1,4$-linked xylan backbone; C: $\alpha-1,2-$ linked L-arabinose. Source: Buanafina, 2009.The occurrence and structural characteristics of other types of xylan have been reported in detail in previous review papers (Ebringerová \& Heinze, 2005; Ebringerová et al., 2005).

\subsection{Lignin}

Lignin is the second is the second most abundant polymer in the cell wall of vascular plants and in nature, after cellulose. Aproximately $20 \%$ of the total carbon fixed by photosynthesis in land ecosystems is incorporated into lignin. It is a complex and recalcitrant aromatic polymer, without defined repetitive units (Hammel \& Cullen, 2008), its precursors are three $p$-hydroxycinnamyl alcohols or monolignols ( $p$-coumaryl, coniferyl and sinapyl) and their recently reported acylated forms (Ralph et al., 2004; Martínez et al., 2008) (Fig. 5).

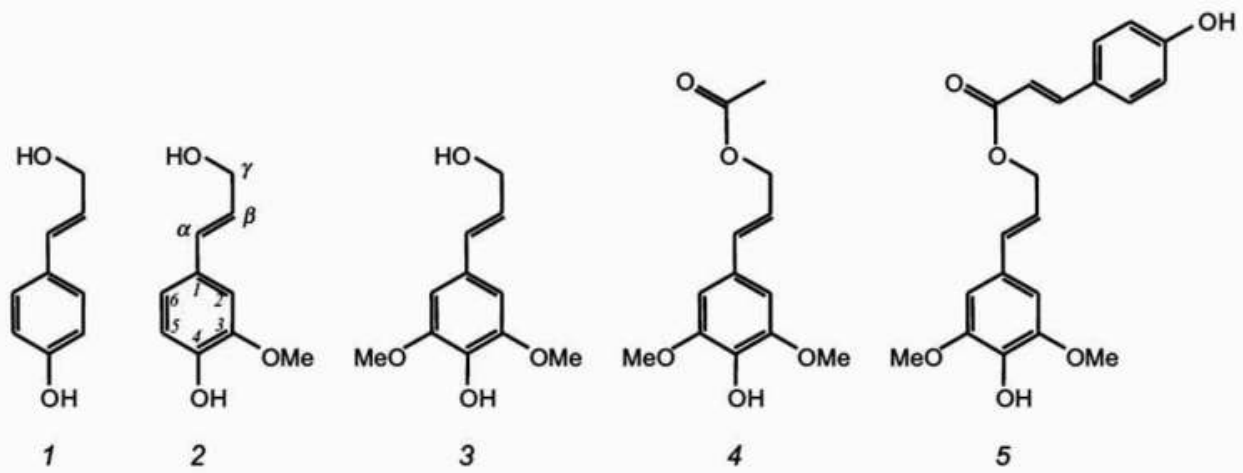

Fig. 5. Lignin precursors or monolignols. Classical: $p$-coumaryl (1), coniferyl (2), sinapyl (3). Acylated: derived from sinapyl alcohol $\gamma$-esterified with acetic (4) and $p$-coumaric acid (5). Source: Ruiz-Dueñas \& Martínez, 2009 - partially reproduced 
Although these precursors are phenolic compounds, the polymer is basically non-phenolic (Fig. 6), due to the high frequency of ether linkages between the phenolic position (C4) and a side-chain (or aromatic ring) carbon of the $p$-hydroxyphenylpropenoid precursors (Fig. 6, substructures A, B and D), strongly predominant in the growing polymer. Unlike cellulose and hemicelluloses, the lignin polymerization mechanism (based on resonant radical coupling) results in a complex three-dimensional network. During the polymer synthesis, a variety of ether and carbon-carbon inter-unit linkages are formed, resulting in many substructures, such as those shown in Figure 6 (Ruiz-Dueñas \& Martínez, 2009).

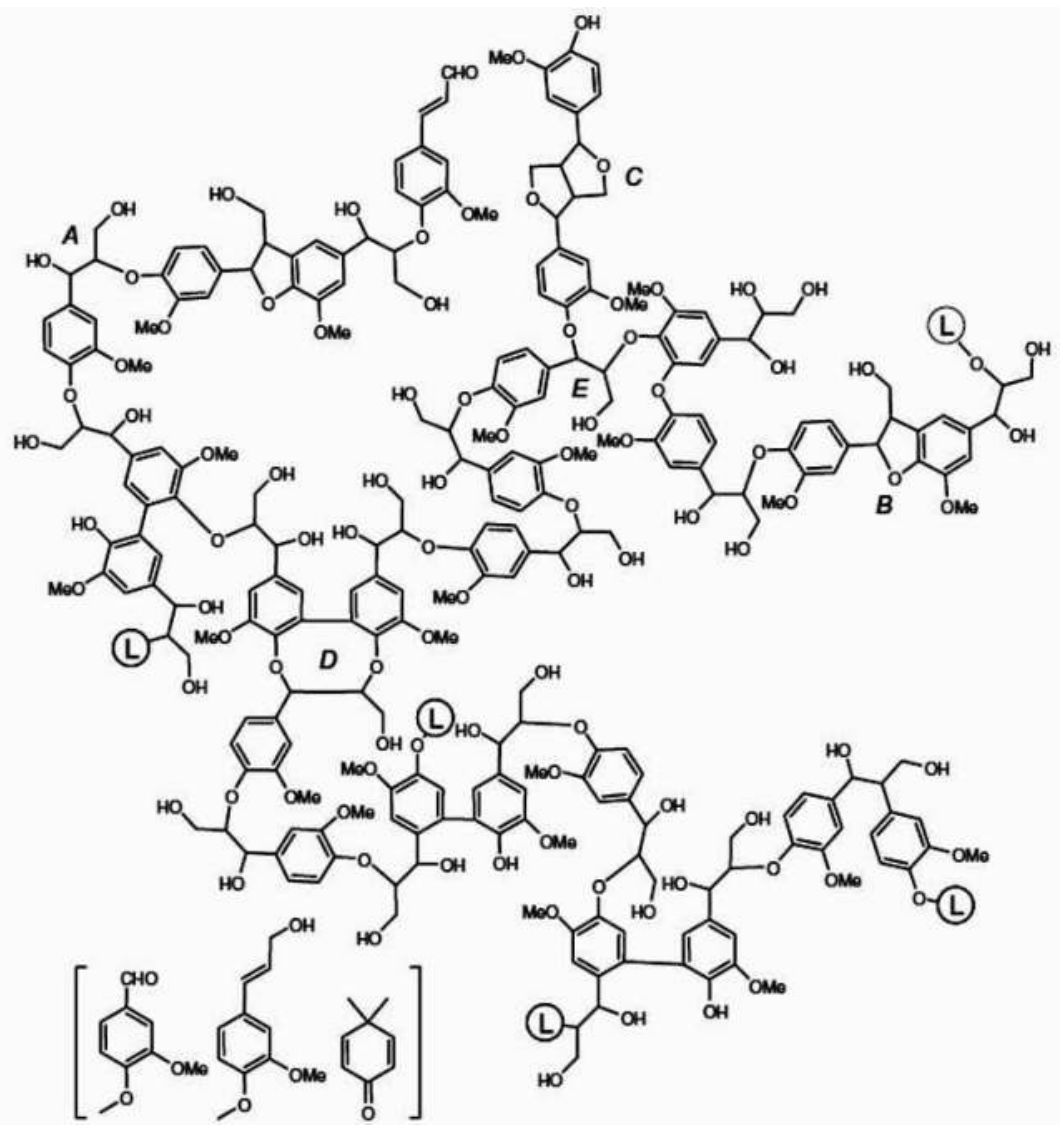

Fig. 6. Lignin structure. Substructures: $\beta-O-4^{\prime}(\mathrm{A})$; phenylcoumaran (B); pinoresinol (C) and dibenzodioxocin (D). L-containing circles indicate linkages to additional lignin chains.

Brackets indicate other minor structures, such as vanillin, coniferyl alcohol and dimethylcyclohexadienone-type units, the latter in new spirodienone substructures. Source: Ruiz-Dueñas \& Martínez, 2009 - partially reproduced.

The association of lignin and hemicelluloses occurs through covalent linkages (such as benzyl ester bonds with the carboxyl group of 4-O-methyl-d-glucuronic acid in xylan and more stable ether bonds between lignin and arabinose or galactose side groups in xylans 
and mannans) (Kuhad et al., 1997) and also through noncovalent linkages. These interactions form a dense and organized network that surrounds the cellulose through extensive hydrogen bonding (Fig. 1) (Westbye $t$ al., 2007). This network protects the cellulose and is one of the reasons for biomass recalcitrance. These lignin-carbohydrate complexes (LCC) represent an obstacle for lignocellulose bioconversion processes because lignin hinders enzyme-mediated hydrolysis of carbohydrates, since it acts as a physical barrier, restricting enzyme access to carbohydrates (Mooney et al., 1998). Lignin may also interact with enzymes possibly through hydrophobic interactions resulting in nonproductive binding (Sutcliffe \& Saddler, 1986).

\section{Lignocellulose-degradating enzymes}

Lignocellulosic materials represent an important source of added-value chemicals, such as reducing sugars, furfural, ethanol and other products that can be obtained by enzymatic or chemical hydrolysis. Enzyme-catalyzed hydrolysis of lignocellulosic biomass provides better yields without the generation of side products (Demirbas, 2008).

Enzymatic degradation of vegetable biomass by microorganisms is carried out by a complex mixture of enzyme, amongst which cellulases and hemicellulases stand out, whose action results in free carbohydrates that may be hydrolyzed to soluble saccharides that can be further metabolized, besides ligninases, which promote lignin depolymerization. Most carbohydrate hydrolases are modular proteins that, besides the catalytic site, have a carbohydrate-binding module (CBM) (Jørgensen et al., 2007). CBMs were first discovered on cellulases but it is now evident that many carbohydrate hydrolases acting on insoluble but also soluble polysaccharides have CBMs, which function is to bring the catalytic site in close contact with the substrate and ensure correct orientation. Furthermore, for some CBMs a disruptive effect on the cellulose fibers has also been shown (Boraston et al., 2004).

\subsection{Cellulases}

The production of cellulases by microrganisms occurs, mainly, by bacteria and filamentous fungi, with few reports of production by yeasts. Ascomycetes and imperfect fungi have great importance for degradating cellulose and decomposing soil vegetable residues, being known as brown rot fungi (Sandgren \& Hiberg, 2005).

A cellulolytic system based on 'free' enzymes, that act synergistically to complete cellulose degradation, is typically produced by aerobic fungi and bacteria. This enzyme system includse three types of cellulases (Fig. 7):

i. Endoglucanases (EG, endo-1,4- $\beta$-D-glucan 4-glucanohydrolase, EC 3.2.1.4): hydrolyses, at random, $\beta-1,4$ glucosidic bonds at internal amorphous sites in the cellulose chains, providing more ends for the cellobiohydrolases to act upon;

ii. Exoglucanases or cellobiohydrolases $(\mathrm{CBH}, 1,4-\beta-\mathrm{D}$-glucan cellobiodehydrolase, EC 3.2.1.91): act on the reducing (CBH I) or nonreducing (CBH II) ends of cellulose chains, liberating cellobiose;

iii. $\beta$-glucosidases ( $\beta$-glucoside glycosyl hydrolase or cellobiase, EC 3.2.1.21): hydrolyze cellobiose or cello-oligosaccharides to glucose and are also involved in transglycosylation reactions of $\beta$-glucosidic linkages of glucose conjugates (Coughlan \& Ljungdahl, 1988). 

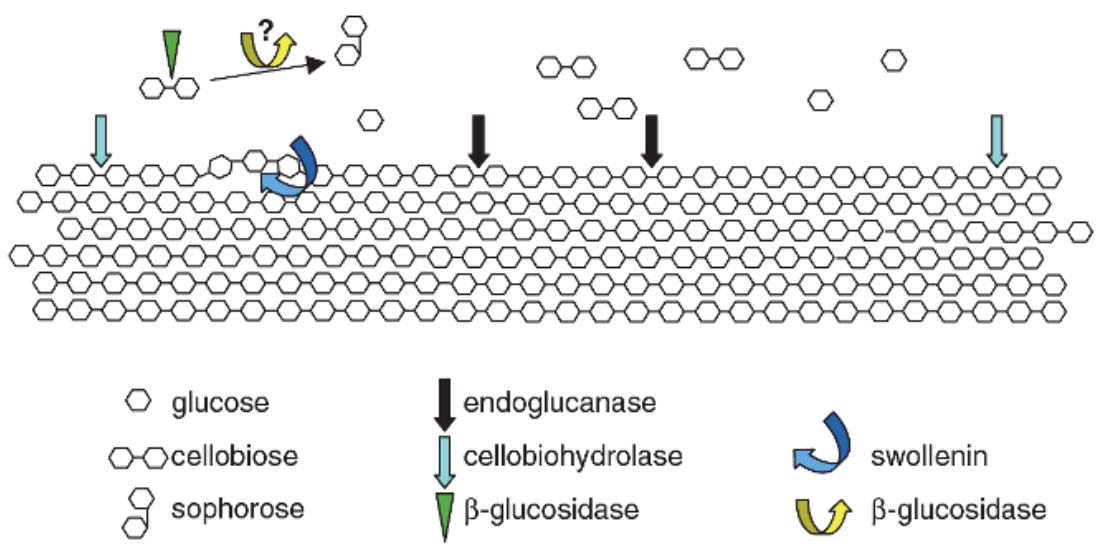

Fig. 7. Schematic representation of the cellulolytic system. Sites of intense cellulolytic enzyme activity are shown, besides an alternative path for the formation of sophorose by $\beta$ glicosidase's tranglycosylating activity. Source: Aro et al, 2005.

In addition to the classical cellulases, Figure 7 also shows the action of swollenins, proteins with amino acid similarity to plant expansins that regulate cell wall enlargement in growing cells. Expansins were firstly isolated from Trichoderma reesei in 1992 and are thought to disrupt hydrogen bonding between cellulose microfibrils or between cellulose and other cell wall polysaccharides, without hydrolyzing them, causing sliding of cellulose fibers or expansion of the cell wall (Whitney et al., 2000). It has been reported that swollenin action helps enzymatic cellulose degradation since it causes a partial damage and loose structure on cellulose, similar to that caused by ultrasound treatment, without releasing reducing sugar (Saloheimo, et al. 2002)

The enzymes of the cellulolytic complex may be subject to catabolic repression by the final product of hydrolysis. For preventing accumulation of celobiose, $\beta$-glicosidase is responsible for controling the overall speed of the cellulolytic hydrolysis reaction, exhibiting a crucial effect on the polymer's enzymatic degradation (Leite et al., 2008).

Cellulases synthesized by anaerobes, particularly clostridia and rumen microorganisms, frequently assemble into a large multienzyme complex (molecular weight $>3 \mathrm{MDa}$ ) termed cellulosome and first identified in 1983 from the thermophilic and spore-forming Clostridium thermocellum (Lamed et al., 1983). This bacterial cellulosome shows very high activity on crystalline cellulose ("true cellulase activity" or Avicelase) which is not commonly observed among fungal cellulases (Johnson et al., 1981).

In C. thermocellum, cellulolytic enzymes are typically distributed both in the liquid phase and on the surface of the cells. However, several anaerobic species that degrade cellulose do not release measurable amounts of extracellular cellulase, and instead have localized their complexed cellulases directly on the surface of the cell or the cell-glycocalyx matrix (Lynd et al., 2002).

Besides Clostridium and other anaerobic bacteria, evidences suggest the presence of cellulosome in at least one aerobic bacterium and a few anaerobic fungi such as Neocallimastix, Piromyces and Orpinomyces (Fanutti et al., 1995; Li et al., 1997).

In addition to cellulases, cellulosomes include xylanases, mannanases, arabionfuranosidases, lichenases, and pectin lyases (Bayer et al., 2004). 
The structure and function of bacterial cellulosomes have been reviewed several times elsewhere (Bayer et al., 1998; Nordon et al., 2009). All cellulosome described share some characteristics (Fig. 8): their enzymes are linked to noncatalytic modules, called dockerins, by carbohydrate-binding modules (CBMs). Dockerins bind, by calcium-dependent interactions, to the cohesin modules, located in a large noncatalytic protein that acts as a scaffoldin. In general, the scaffoldin, a large and distinct protein, allows binding of the whole complex to the plant cell wall, via a cellulose-specific family 3 CBM (CBM3a), and to the bacterial cell via a C-terminal divergent dockerin (Fontes \& Gilbert, 2010).

Since the recalcitrance and chemical complexity of some polymers represent an obstacle to the enzymatic degradation of lignocellulose, more efficient enzyme systems are required. Cellulosomes highlight as one of nature's most elaborate nanomachines and the arrangement of plant cell wall degrading enzymes into this complex has advantages over free enzyme systems. Less total protein may be required to solubilize cellulose, including crystalline cellulose, which suggests that specific activity of the cellulosome for such substrates is higher than that of free enzyme systems (Johnson et al., 1982; Boisset et al, 1999). We could say that cellulosome enzymes are "concentrated" and positioned in a suitable orientation both with respect to each other and to the cellulosic substrate, thereby facilitating stronger synergism among the catalytic units. Due to this optimum spacing of the components, working in a synergistic manner, non-productive adsorption is avoided. Since cellulosome is close to the microorganism cell surface, hydrolysis inhibitory products would not accumulate, but would be maintained at appropriate concentrations for most efficient use by the cell (Shoham et al, 1999).

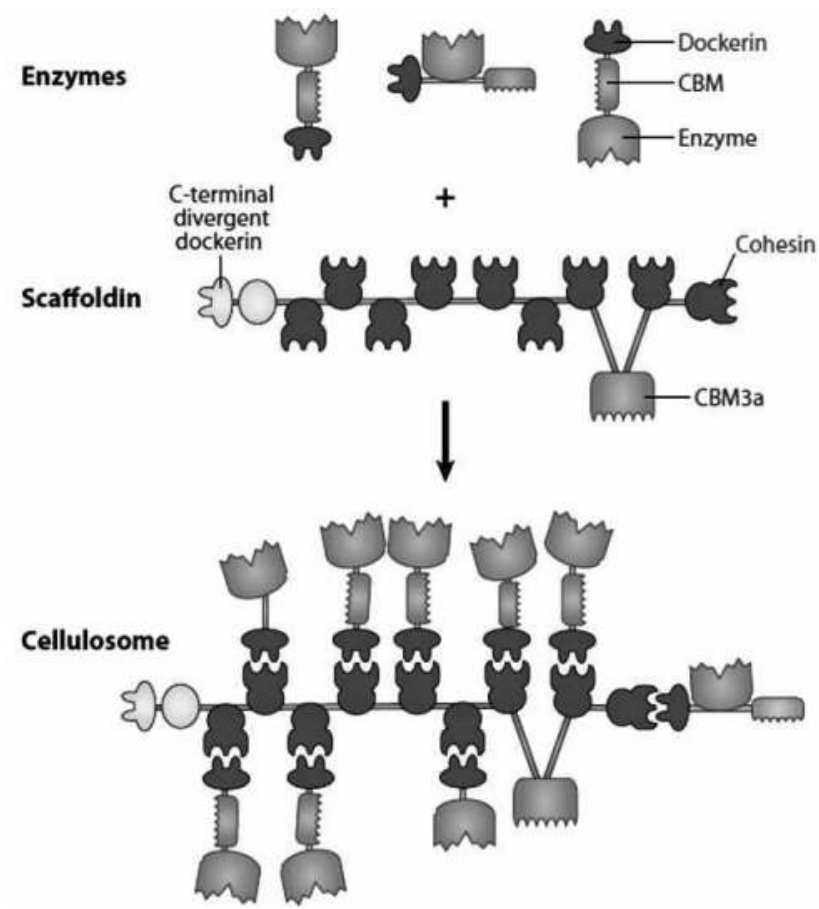

Fig. 8. Mechanism of cellulosome assembly. Source: Fontes \& Gilbert, 2010. 


\subsection{Xylanases}

Due to xylans heterogeneity and complexity, the complete hydrolysis of this polysaccharide requires the action of an enzyme system with different specificities and ways of action (Fig. 9). The microbial systems are made up by (Wong et al., 1988):

i. Endo-1,4- $\beta$-D-xylanases (EC 3.2.1.8): hydrolyze $\beta-1,4$ glycosidic linkages between xylose residues in the backbone of xylans;

ii. 1,4- $\beta$-D-xylosidases (EC 3.2.1.37): release $\beta$-D-xylopyranosyl residues from the nonreducing terminus of xylobiose and some small $4-\beta$-D-xylooligosaccharides;

iii. $\quad \alpha$-L-arabinofuranosidases (EC 3.2.1.55): removes L-arabinose side chains from the xylose backbone of arabinoglucuronoxylan;

iv. $\alpha$-glucoronidases (EC 3.2.1.1): hydrolyzes the $\alpha-1,2$ glycosidic bonds between the glucuronic acid residues and $\beta$-D-xylopyranosyl backbone units found in glucuronoxylan;

v. acetyl xylan esterases (EC 3.1.1.72): removes the $O$-acetyl groups from positions 2 and/or 3 on the $\beta$-D-xylopyranosyl residues of acetyl xylan

vi. $\quad$-coumric and ferulic acid esterases (EC 3.1.1.1): cleave ester bonds on xylan, between arabinose and erulic acid sidegroups and between arabinose and p-coumaric acid, respectively (Christov \& Prior 1993).

The feruloyl esterases exhibit a key role providing an increase on hydrolytic enzyme's accesability on hemicellulose fibers due to the removal of ferulic acid from the side chains and cross links (Wong, 2006).

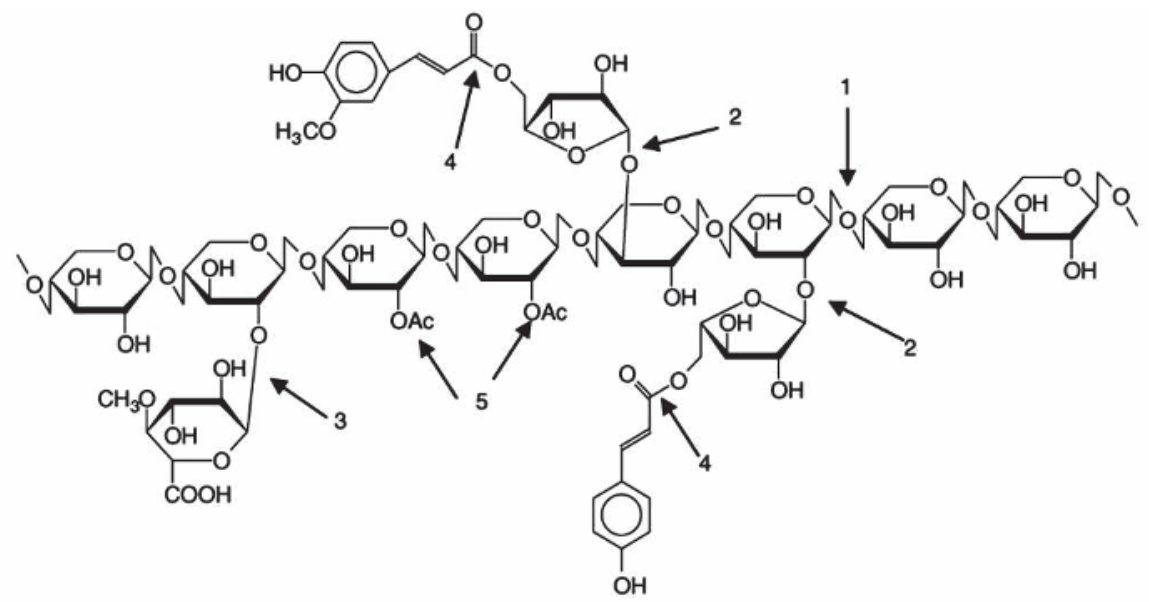

Fig. 9. Schematic representation of the action of the xylanolytic enzyme system. 1 endoxylanases; 2 - $\alpha$-L-arabionofuranosidases; 3 - glucuronidases; 4 - feruloyl and coumaroyl esterases; 5 - acetyl xylan esterases; $6-\beta$-xylosidases. Source: Chávez et al., 2006

All xylanolytic enzymes act in a cooperative way to convert xylan into its monomers (Wong et al., 1988). Such multifunctional xylanolytic system may be found in fungi and bacteria (Sunna \&Antranikian, 1997), including the actinomycete (Elegir et al., 1995). Some of the most important microrganisms that produce xylanolytic enzymes belong to the genera 
Aspergillus, Trichoderma, Streptomyces, Phanerochaete, Clotridium e Bacillus (Collins et al., 2005; Subramaniyan \& Prema, 2002).

\subsection{Ligninases}

Lignin decomposition is indispensable for carbon recycling since it is the most abundant renewable source of aromatic polymer in nature. Due to its complex and heterogeneous structure, lignin is chemically recalcitrant to breakdown by most organisms. Only the basidiomycetous, called whiterot fungi, are able to degrade lignin efficiently by producing an array of extracellular oxidative enzymes that act synergistically. Among these enzymes, the major groups include lignin peroxidases, manganese peroxidases, and laccases (Wong, 2009).

\subsubsection{Laccases}

Laccase (E.C. 1.10.3.2) is a multicopper protein belonging to the family of the blue oxidase enzymes. This enzyme generally contains four copper ions, grouped in three groups: T1, formed by one ion and is responsible for substrate oxidation and for electron transfer; $\mathrm{T} 2$, also formed by one ion and, together with the T3 group, which contains two ions, constitute the copper trinuclear center, involved in oxygen reduction and water release (Torres et al., 2003). Copper located at the T1 site is the one responsible for the strong absorption of the enzyme at the $600 \mathrm{~nm}$ range; however there has been reports of laccases with copper deficiency at T1, called white laccases, due to the absence of the characteristic absorbance at the blue range (Baldrian, 2006).

Laccase is classified as a phenol oxidase and catalyzes the oxidation of various aromatic and inorganic compounds (phenols in particular) and at the same time reduces oxygen to water. Phenolic dyes, phenols, chlorophenols, some diphenylmethanes and benzopirenes are amongst the substrates oxidized by this enzyme (Durán \& Esposito, 2000). Laccase can degrade lignin even in the absence of other ligninases, such as manganese peroxidase and lignin peroxidase (Mayer \& Staples, 2002).

The catalytic mechanism is based on the reduction of molecular oxygen forming water, at the expense of consecutive monoeletronic oxidation of the substrate.

Laccases may directly interact with phenolic substrates and oxidize them, however they are not capable of directly acting on aromatic non-phenolic molecules, thus requiring a mediator molecule for the degradation of such compounds. In this laccase-mediator mechanism, the mediators oxidize substrates of high molecular mass (Torres et al., 2003). Generally, the mediators are low molecular weight substances, secreted by the fungi itself, which when oxidized by laccases, are capable of oxidizing compounds that would not be the enzyme's direct target. The mediation phenomenon increases the range of substrates of these enzymes (Leonowicz et al., 1999)

\subsubsection{Lignin peroxidases (LiP)}

Lignin peroxidase (LiP) (E. C. 1.11.1.14) is a glycoprotein that has a prosthetic group made up of iron protoporphirin IX, with catalytic activity dependent on $\mathrm{H}_{2} \mathrm{O}_{2}$ (Rodriguez \& Durán, 1988). The $\mathrm{H}_{2} \mathrm{O}_{2}$ required for LiP acitivy is originated from different biochemical pathways, expressed according to the nutritional factors and growth conditions of the microrgansim (Pointing, 2001).

$\mathrm{LiP}$ is an enzyme capable of oxidizing various non-phenolic aromatic compounds such as benzyl alcohol, cleaving side chains of these compounds, catalyzing aromatic ring opening reactions, demetoxilation and oxidative dechlorination (Conessa et al., 2002). 
Veratrilic alcohol may induce enzyme's action, protect it against activation by high levels of $\mathrm{H}_{2} \mathrm{O}_{2}$, besides acting as co-substrate, carrying out oxidation of the non-phenolic aromatic compounds (Mester et al., 1995; Pointing, 2001).

\subsubsection{Manganese peroxidases (MnP)}

Manganese peroxidase (MnP, E. C. 1.11.1.13) is a glycosylated extracellular enzyme that has an heme prosthetic group, found only in basidiomycetes. In general, it does not unleash direct transformations on its substrates. The electron transfers involving manganese happen in the presence of dicarboxylic radicals, such as oxalate, malate, fumarate and malonate (Leonowicz et al., 1999). These radicals are $\mathrm{Mn}^{3+}$ chelating agents. When complexed, apparently, they act as low molecular weight mediators which will effectively oxidize lignin's phenolic compounds (Higuchi, 2004). $\mathrm{MnP}^{\prime}$ s reaction mechanism is similar to that of other peroxidases, such as lignin peroxidase but, in this case, compounds I and II of MnP oxidize $\mathrm{Mn}^{2+}$ (Conessa et al., 2002).

\section{Solid state fermentation (SSF) and its application on the cultivation of microrganisms that produce lignocellulolitic enzymes}

SSF can be defined as the cultivation of microrganisms in a solid insolubel matrix, in the presence of enough water to only support microbial growth (held in the particles). The solid matrix may be used by the microrganism as substrate, or may just serve as as innert support for growth (in this last case, it should be soaked in a nutrient solution) (Pandey et al., 2000). The selection of an appropriate substrate is a key factor for the success of SSF. Besides having the adequate compostition to induce the desired product, the particles size should also be considered, since this is a factor that greatly influences SSF. Small particles offer more contact surface, allowing more access of the microorganism to the nutrients; however, depending on the type of substrate and on the moisture level, it can get compacted, impairing aeration and oxygen availability, as well as heat dissipation, limiting microbial growth. Big particles, on the other hand, facilitate aeration, however may hinder microbial access, limiting substrate contact surface and making heat transfer difficult (PALMA, 2003). Other parameters should also be evaluated and optimized for higher process efficiency, such as initial moisture and $\mathrm{pH}$, incubation temperature, aeration, inoculum size, nutrient supplementation, extraction and purification of the final product (Pandey, 2003).

Solid state fermentation (SSF) is an interesting process for lignocellulose-degrading enzymes production at low cost, due to the possibility of using agricultural and agroindustrial residues as substrate for microbial growth. Filamentous fungi are considered to be the most adapted microrgansims for SSF, since their hyphae may grow on the particles surface and penetrate the intra-particle spaces, and thus colonize solid substrates (Santos et al, 2004). In a general way, the demands of high water activity for the development of bacteria make them not adaptable to SSF processes. However, scientific reports have shown that some bacterial cultures may be adapted to this type of process (Nampoothiri \& Pandey, 1996; Orozco et al., 2008).

Fig. 10 is a schematic representation of some biological and physical processes that take place during SSF. During a process of solid-state fermentation, fungi grow by forming a mycelial mat on the surface of the particles that comprise the solid substrate. Aerial hyphae protrude into the gaseous space and penetrative hyphae grow into liquid-filled pores. Unless the moisture is above the appropriate level, the empty spaces between the aerial 
hyphae are filled with gas (g), whereas the empty spaces within the mycelial mat and within the substrate are filled with liquid (l). Near the substrate surface and within the pores are regions of most metabolic activities. However, the regions of aerial hyphae also show metabolism and there can be a transport of substances from the penetrative to the aerial hyphae. By producing hydrolytic enzymes that diffuse into the solid matrix, fungi can degrade macromolecules into smaller units which are taken up by mycelium to serve as nutrients. During fermentation, there is consumption of $\mathrm{O}_{2}$ and production of $\mathrm{CO}_{2}, \mathrm{H}_{2} \mathrm{O}$, other biochemical products and heat. Gradients develop within the biofilm that, for instance, force $\mathrm{O}_{2}$ to diffuse from the gaseous phase into deeper regions of the biofilm and $\mathrm{CO}_{2}$ to diffuse from these regions to the gaseous phase. Heat is removed from the substrate via conduction and also by evaporation, which is part of the complex balance of water in the system. The release of organic acids and ammonia might change the local pH (Hölker \& Lenz, 2005).

The use of SSF for fungi cultivation presents many advantages, such as: simulation of their natural environment, which results in better adaptation to the medium and higher enzymatic productions; reduction of bacterial contamination, due to absence of free water; obtainment of more concentrated enzymes, once the enzymatic extracts may be extracted with small amounts of water (Bianchi et al, 2001). Other advantages of fungal enzyme production by SSF can also be mentioned when comparing it to submerged fermentation, such as use of lesser amount of water and consequently a decrease in effluent generation, lower requirement of space and energy, more stability of the obtained products, more biomass and enzyme production, less catabolic repression of enzymes and little protein degradation (Pandey et al., 2000; Viniegra-González et al., 2003).

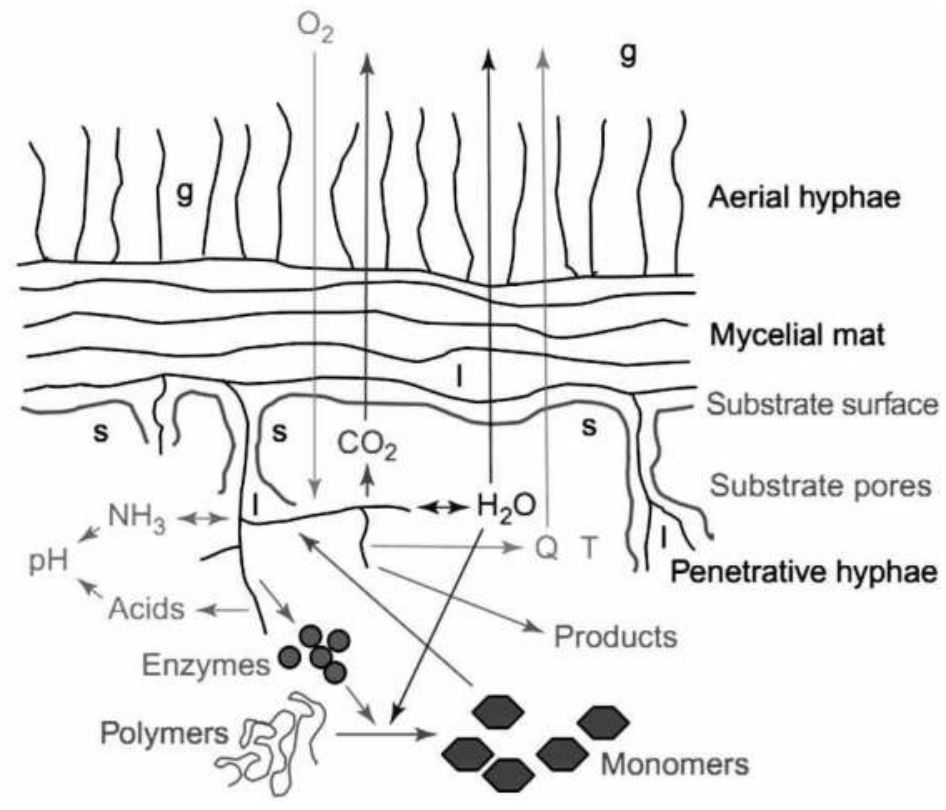

Fig. 10. A scheme of some microscale processes that occur during solid-state fermentation (SSF). Source: Holker \& Lenz, 2005. 
The main disadvantages of using SSF are the difficulty of heat dissipation. Temperature is directly related to water activity (aw) and aeration. The low thermal conductivity of the solid medium limits the removal of excess heat generated by microbial metabolism in SSF. In practice, SSF requires aeration mostly to dissipate heat rather than to provide oxygen (Viesturs et al., 1981). The temperature increase in bioreactors may cause protein denaturation, especially of the thermolabile ones (Santos et al., 2004). In this matter, thermophilic fungi encourage special interest for enzyme production processes by SSF. By exhibiting optimum growth at 45 and $55^{\circ} \mathrm{C}$, such microorganisms better endure the possible temperature raise due to the difficulty of heat dissipation in SSF, especially in large-scale bioreactors, as well as secrete enzymes that are more active and stable at higher temperatures, which present many important properties from the industrial application point of view (Maheshwari et al., 2000).

Scale-up represents another obstacle to be overcome in SSF processes, once different gradients (moisture, temperature, substrate concentration and others) form along the bioreactor, which may negatively influence the process, especially the static bed ones. Heat dissipation, mass transfer and control of the fermentative parameters are the main challenges to be overcome in this sense (Hölker \& Lenz, 2005; Khanahmadia et al., 2006). It is worth mentioning that, in the last decades, researches on design, modeling, operation and scaling up have brought progress to the knowledge of SSF processes involving bioreactors (Mitchell et al., 2000).

\section{Lignocellulosic residues: Substrates for the production of microbial enzymes and source of fermentable sugars for second generation ethanol production}

Agricultural, industrial, forestry and urban solid residues are abundant sources of lignocellulose available worldwide that, in the past, were treated as waste in many countries (Dashtban et al., 2009). In some countries, these materials are still treated as wastes, disposed in the environment, many times without an adequate treatment, raising environmental damage. In other countries, they are also used to generate thermal energy by traditional (firing for cooking and heating) or modern uses (producing electricity and steam, and liquid biofuels) (Dawson \& Boopathy, 2007; Kim \& Dale, 2004).

With the increasing expansion of agro-industrial activities, large quantities of lignocellulosic residues are generated annually worldwide (Sanchéz, 2009). In Brazil, according to the data cited by Ferreira-Leitão et al. (2010), the agroindustry of corn (13767400 ha), sugarcane (7080920 ha), rice (2890930 ha), cassava (1894460 ha), wheat (1853220 ha), citrus (930591 ha), coconut (283205 ha), and grass (140000 ha) collectively occupies an area of 28840726 ha and generates 597 million tons of residue per year.

Biotechnological innovations bring many significant and successful efforts to convert lignocellulosic residues into valuable products including enzymes for biotechnological and industrial applications (Leite et al., 2008; Tengerdy \& Szakacs, 2003). However, the cost to produce these enzymes is still an obstacle that needs to be overcome. Therefore, the use of agroindustrial residues as carbon source for fungal growth and ligno/hemi/cellulolitic enzyme production through solid state fermentation (SSF) has been reported in many studies as a way of significantly reducing process cost. Many agricultural and agroindustrial by-products are used in SSF processes for the production of cellulases, xylanases and ligninases, among other enzymes (Table 1) (Gao et al., 2008; Kang et al., 2004). 
As previously mentioned fungi are better adapted to SSF and are able to produce copious amounts of cellulases and hemicellulases which are secreted to the medium for easy extraction and purification. Their enzymes are often less complex than bacterial glycoside hydrolases and can therefore be more readily cloned and produced via recombination in a rapidly growing bacterial host, such as Escherichia coli (Maki et al., 2009). Besides, there are the white-rot fungi that significantly contribute to lignocellulose conversion since they are the best producers of the lignin degrading enzymes. Table 1 shows a few examples of lignocellulose-degrading enzymes produced by fungi in SSF.

Lignocellulosic residues can also be used to obtain biofuels like bioethanol, named second generation or cellulosic ethanol. New technologies promote the hydrolysis of the carbohydrate fraction of these residues into fermentable sugars that are converted into ethanol by fermenting microorganisms. This technology contrasts with the conventional first generation ethanol production, where carbohydrates of the edible portion (starch, sugar, oils, etc.) of food-based crops are used to be converted into ethanol (Balat et al., 2008).

Among lignocellulosic materials, crop residues are the major potential feedstock for second generation bioethanol production. Table 2 shows the composition of some crops and residues in terms of lignin and carbohydrates, besides the potential yield of second generation ethanol (Kim \& Dale, 2004).

With the increase of world population and of the use of fossil fuels, together with constant climate changes, the search for sources of renewable energy has become more necessary, through the coordinated and sustainable actions, in environmental, social and economical aspects. So far, many countries have invested in research to introduce and ensure the prevalence of bioethanol on the market. In this context, Brazil stands out for having an energetic matrix with $46 \%$ of renewable sources, more than half of them represented by agroenergy, in a world where the use of these sources is of only approximately $15 \%$ It is the first country to regulate the mandatory addition of a certain percentage of ethanol into motor fuel. In 1975, the Brazilian government implemented the Proálcool (Alcohol National Program) for the large scale substitution of petroleum originated vehicle fuels, due to the petroleum crises in 1973 and 1979. This program greatly contributed to the country's alcohol and sugar sector development. Currently, sugarcane and its by-products are the second major source of primary energy of the national energetic matrix and the use of ethanol is already superior to that of gasoline. This experience has won over the world and Brazil has become reference in this area (Statistical Yearbook AgriEnergy, 2009).

In Brazil, first generation ethanol is produced from sugarcane broth, a readily fermentable material, once the substrate (sucrose) is directly used by the fermentative agent, Saccharomyces cerevisiae. In the United States alcohol fuel is produced from corn starch, meanwhile in Europe (except for France, which uses beet sugar) wheat and barley starch are mainly used. In both cases, enzymatic hydrolysis of starch is employed, and these countires have, therefore, industrial experience in the use of enzymes for bioethanol production (Bon et al., 2008).

Presently, Brazil ranks No. 1 in using first generation ethanol, obtained from sugarcane broth, with the highest rate in the world (Wang et al., 2011). The country's interest in developing biofuels has driven researches and investments for the diversification of the national energetic matrix. Therefore, the use of sugarcane bagasse (the fibers which are left after milling), a lignocellulosic residue widely available in the country, stands out as a new technology to be explored for the production of second generation ethanol. 


\begin{tabular}{|c|c|c|c|}
\hline Enzymes & Fungi & Substrates & Reference \\
\hline \multirow[t]{5}{*}{ Endoglucanase } & Trichoderma reesei QM9414 & Rice bran & $\begin{array}{l}\text { Rocky-Salimi \& } \\
\text { Hamidi-Esfahani, } \\
2009\end{array}$ \\
\hline & Aspergillus terreus M11 & $\begin{array}{l}\text { Wheat bran and } \\
\text { straw, corn cob, reed } \\
\text { straw, sugarcane } \\
\text { bagasse }\end{array}$ & Gao et. al, 2008 \\
\hline & Myceliophthora sp. IMI 387099 & Rice straw & Badhan et. al, 2007 \\
\hline & Fusarium oxisporum F3 & Corn Cob & Panagiotou et al., 2003 \\
\hline & Aspergillus Níger 38 & Wheat straw and bran & Jecu, 2000 \\
\hline \multirow[t]{2}{*}{$\beta$-glucosidase } & Aspergillus sydowii BTMFS 55 & Wheat bran & Madhu et al., 2009 \\
\hline & $\begin{array}{l}\text { Thermoascus aurantiacus CBMAI } \\
456 \text { and Aureobasidium pullulans } \\
\text { ER-16 }\end{array}$ & $\begin{array}{l}\text { Wheat bran, soy bran, } \\
\text { soy peel, corncob and } \\
\text { corn straw }\end{array}$ & Leite et al., 2008 \\
\hline \multirow[t]{5}{*}{ Xylanase } & Neosartorya spinosa D19 & Wheat bran & $\begin{array}{l}\text { Alves-Prado et al., } \\
2010\end{array}$ \\
\hline & Aspergillus terreus & Palm waste & Lakshmia et al, 2009 \\
\hline & Coprinellus disseminatus & Wheat bran & Singh et al., 2009 \\
\hline & Aspergillus carneus M34 & $\begin{array}{l}\text { Soybean Shell, Rice } \\
\text { bran }\end{array}$ & Fang et al., 2009 \\
\hline & Fomes sclerodemeus & Wheat bran & $\begin{array}{l}\text { Papinutti \& } \\
\text { Forchiassin, } 2007\end{array}$ \\
\hline \multirow[t]{6}{*}{ Laccase } & Coriolopsis byrsina & Wheat bran & Gomes et al., 2009 \\
\hline & Lentinus tigrinus BAFC 197 & Wheat straw & $\begin{array}{l}\text { Lechner \& Papinutti, } \\
2006\end{array}$ \\
\hline & Pleutorus sp & Coconut coir & $\begin{array}{l}\text { Bhattacharya et al., } \\
2011\end{array}$ \\
\hline & $\begin{array}{l}\text { Pleurotus ostreatus } \\
\text { MTCC1804 and Anacystis } \\
\text { nidulans IU625 }\end{array}$ & Peanut shell & $\begin{array}{l}\text { Mishra \& Kumar, } \\
2006\end{array}$ \\
\hline & Trametes versicolor & Horticultural wastes & Xin \& Geng, 2001 \\
\hline & Trametes versicolor & Sugarcane bagasse & Pal et al., 1995 \\
\hline \multirow{5}{*}{$\begin{array}{l}\text { Manganese } \\
\text { peroxidase }\end{array}$} & Lentinus sp & Wheat bran & Gomes et al., 2009 \\
\hline & Fomes sclerodemeus & & $\begin{array}{l}\text { Papinutti \& } \\
\text { Forchiassin, } 2007\end{array}$ \\
\hline & $\begin{array}{l}\text { Pycnoporus } \\
\text { Cinnabarinus }\end{array}$ & Wood & Alves et al., 2004 \\
\hline & Ceriporiopsis subvermispora & Wood waste & Ferraz et al., 2003 \\
\hline & P. chrysosporium & Wheat straw & Fujian et al., 2001 \\
\hline \multirow{5}{*}{$\begin{array}{l}\text { Lignin } \\
\text { peroxidase }\end{array}$} & Lentinus $\mathrm{sp}$ & Wheat bran & Gomes et al., 2009 \\
\hline & Poliporus sp, Hexagonia sp & Wheat bran & Abrahão et al., 2008 \\
\hline & Pleurotus sajor-caju & Banana waste & Reddy et al, 2003 \\
\hline & $\begin{array}{l}\text { Pleurotus ostreatus, Phanerochaete } \\
\text { chrysosporium }\end{array}$ & sugarcane bagasse & Pradeep \& Datta, 2002 \\
\hline & P. radiate & corn straw & Vares et al., 1995 \\
\hline
\end{tabular}

Table 1. Production of enzymes related to the degradation of vegetable material by fungi cultivation in SSF, using agricultural residues as substrate. 


\begin{tabular}{|c|c|c|c|c|c|}
\hline Biomass & $\begin{array}{c}\text { Residue/crop } \\
\text { ratio }\end{array}$ & $\begin{array}{c}\text { Dry } \\
\text { matter }\end{array}$ & Lignin $^{1}$ & Carbohydrates ${ }^{1}$ & $\begin{array}{l}\text { Ethano } \\
\text { yield }^{2}\end{array}$ \\
\hline Barley & 1.2 & 88.7 & 2.90 & 67.10 & 0.41 \\
\hline Barley Straw & & 81.0 & 9.00 & 70.00 & 0.31 \\
\hline Corn & 1.0 & 86.2 & 0.60 & 73.70 & 0.46 \\
\hline Corn stover & & 78.5 & 18.69 & 58.29 & 0,29 \\
\hline Oat & 1.3 & 89.1 & 4.00 & 65.60 & 0.41 \\
\hline Oat straw & & 90.1 & 13.75 & 59.10 & 0.26 \\
\hline Rice & 1.4 & 88.6 & & 87.50 & 0.48 \\
\hline Rice Straw & & 88.0 & 7.13 & 49.33 & 0.28 \\
\hline Sorghum & 1.3 & 89.0 & 1.40 & 71.60 & 0.44 \\
\hline $\begin{array}{l}\text { Sorghum } \\
\text { straw }\end{array}$ & & 88.0 & 15.0 & 61.00 & 0.27 \\
\hline Wheat & 1.3 & 89.1 & & 35.85 & 0.40 \\
\hline Wheat straw & & 90.1 & 16.0 & 54.00 & 0.29 \\
\hline Sugarcane & & 20.0 & & 67.00 & 0.50 \\
\hline $\begin{array}{l}\text { Sugarcane } \\
\text { bagasse }\end{array}$ & $0.6^{3}$ & 71.0 & 14.50 & 67.15 & 0.28 \\
\hline
\end{tabular}

${ }^{1}$ Data in percentage; ${ }^{2}$ Data in $\mathrm{L} / \mathrm{Kg}$ of dry biomass; ${ }^{3 \mathrm{~K}} \mathrm{~g}$ of bagasse/Kg of dry sugarcane. (Kim \& Dale, 2004).

Table 2. Composition of some lignocellulosic biomass (based on dry biomass) and potential ethanol yield.

The Brazilian production of sugarcane for sugar and alcohol obtainment was of 563,638,524 milled tons in the 2008/2009 harvest (approximately 78 ton/ha). Ethanol yield per sugarcane ton in this harvest season was of approximately $49 \mathrm{~L}$ or 3,528 L/ha (Statistical Yearbook AgriEnergy, 2009).

In gerenal, the processing of one sugarcane ton generates approximately $280 \mathrm{~kg}$ of bagasse. According to Macedo (2005), about $92 \%$ of sugarcane bagasse is used for heat process. If the remaining $8 \%$ were to be converted to ethanol, then one could expect an additional $2200 \mathrm{~L}$ of ethanol per hectare, bringing the ethanol yield per hectare to $5.728 \mathrm{~L}$, reducing the land use requirements by $29 \%$ (Soccol et al., 2010).

Sugarcane bagasse represents the highest residue percentage of the Brazilian agroindusty, with an average of 75 million tons/year (Teixeira et al., 2007). Although a great part is used for thermal energy generation at the manufacturing plant, the excess bagasse represents a great opportunity for the national agro industry. Therefore, there is broadly recognized that the annual sugarcane bagasse production reaches considerable numbers and that the use of this residue is a national need, with wide space for the development of more noble activities than direct energy generation through combustion. According to a few authors, the use of the excess bagasse makes the investments needed to adapt the sugar and alcohol manufacturing plants economically feasible, solving the supplying problem of the sugar and alcohol industry, offering social and environmental advantages and increasing yield of the economical process (Gamez et al., 2006).

Sugarcane composition varies according to many factors, such as the extraction process, sugarcane variety and soil composition. Generally, it is made up of approximately $32-44 \%$ cellulose, 27-32\% hemicellulose and 19-24\% lignin (Malherbe \& Cloete, 2002; Howard et al., 
2003). This residue presents small amounts of other compounds such as pectin, protein, minerals and low molecular weight compounds, besides having lower ash content (approximately 2.4\%), which represents a great advantage for its bioconversion by microorganisms when compared to other residues such as rice and wheat straw, which contain approximately 17.5 and $11 \%$ ash, respectively. In addition, when compared to other agro industrial residues, bagasse can be considered a rich reservoir of energy due to its high yield (approximately $80 \mathrm{t} / \mathrm{ha}$, when compared to 1, 2 and $20 \mathrm{t} / \mathrm{ha}$ for wheat, grasses and trees, respectively) and annual regeneration capacity (Pandey et al., 2000).

In Brazil, the South-Central region is responsible for approximately $90 \%$ of the sugarcane production and designated an area of 7.01 million hectares for its plantation in 2008. In the São Paulo State alone, 3.82 million hectares (54.5\%) were occupied with this crop. The sugar and alcohol sector in Brazil has been keeping a continuous expansion along the past years, which can be noted by the enlargement of sugarcane planted area, construction of new manufacturing plants throughout the national territory and by the production of ethanol in the country (Teixeira et al., 2007). Often, this expansion raises a number of questions regarding its competitiveness with food crops and the possibility of destruction or damage of high biodiversity areas, deforestation and degradation or damaging of soils through the use of chemicals. Studies have demonstrated that such concerns have been grossly exaggerated (Cerqueira Leite et al., 2009; Goldemberg \& Guardabassi, 2010). Goldenberg et al (2008) reported that, according Instituto de Economia Agrícola - IEA, a large portion of Brazil has conditions to economically support agricultural production while preserving vast forest areas with different biomass. Most expansion on existing sugarcane crops is taking place on degraded and pasture lands (Lora et al., 2006), areas are far from important biomes like Amazon Rain Forest, Cerrado, Atlantic Forest and Pantanal. Goldenberg et al. (2008) also presented in their paper that sugarcane growth does not seem to have an impact in food areas, since the area used for food crops has not decreased between 1990 and 2006, according data from IBGE and IEA. Besides, the amount of fertilizer used is also small compared to sugarcane crops in other countries (48\% more is used in Australia). Authors also consider that there is an increase on ethanol production in Brazil, especially in Sao Paulo State, due to the growth of overall productivity related to the development of new species and to the improvement of agricultural practices.

\section{Pretreatments and enzymatic saccharification of lignocellulosic biomass aiming ethanol production}

\subsection{Types and effects of pretreatments}

One of the major obstacles towards saccharification of the lignocellulosic material is its recalcitrant nature. Heterogenous characteristic of biomass particles, surface area and the presence of hemicellulose-lignin complexes covering cellulose contribute to the resistence of lignocellulosic biomass towards hydrolysis (Chang \& Holtzapple, 2000).

Structural and constitutive factors reflect the complexity of the lignocellulosic material. The variability of these characteristics contributes to the differences of recalcitrance among lignocellulose sources (Mosier et al., 2005). The removal of lignin, the reduction of cellulose cristalinity and the increase of fiber porosity as a means to facilitate enzyme access may significantly improve saccharification of the lignocellulosic material (McMillan, 1994). This way, the bioconversion of lignocellulosic material into ethanol involves many stages which include: a) pretreatment (physical, chemical and/or biological); b) lignin depolymerization 
and carbohydrate hydrolysis; c) conversion of fermentable sugars liberated through the hydrolysis in ethanol and d) ethanol separation and purification.

The objective of any technology related to the pretreatment of lignocellulosic material is to minimize or remove the constraints of hydrolysis, improving enzymatic hydrolysis rate, thus increasing the yield of fermentative sugars. Gererally, pretreatments alter the structure of lignocellulosic biomass, making it more accessible to the action of depolymerizing enzymes.

The success of pretreatments is based on a few factors such as: obtainment of fermentable sugars or of a facilitated subsequent obtainment of these sugars through enzymatic hydrolysis; no formation or low formation of products that may inhibit both enzymatic hydrolysis and the action of fermtative microorganisms; be a low cost technology (Sun \& Cheng, 2002). Studies have shown that the pretreatment step defines at which extension and cost the carbohydrates will be converted into ethanol (Chandel et al., 2007). It should also be mentioned that lignin removal, during the pretreatment, is important due to the possibilities of its industrial use (Gopalakrishnan et al., 2010).

Table 3 shows a few examples of lignocellulosic biomass pretreatments. It should be mentioned that not all of these methods have been completely established in such a way as

\begin{tabular}{|c|c|c|}
\hline & Processes & $\begin{array}{l}\text { Mechamism of changes } \\
\text { on biomass }\end{array}$ \\
\hline Physical & $\begin{array}{l}\text { Ball-milling; Two-roll milling; Hammer } \\
\text { milling; Colloid milling; Vibro energy milling } \\
\text {; Hydrothermal; High pressure steaming; } \\
\text { Extrusion; Expansion; Pyrolysis; Gamma-ray } \\
\text { irradiation; Electron-beam irradiation; } \\
\text { Microwave irradiation. }\end{array}$ & $\begin{array}{l}\text { Increase in accessible } \\
\text { surface area and pores } \\
\text { size; decrease in cellulose } \\
\text { crystallinity and } \\
\text { polymerization degree; } \\
\text { partial hydrolysis of } \\
\text { hemicellulose and lignin } \\
\text { depolimerization }\end{array}$ \\
\hline $\begin{array}{l}\text { Physicochemical } \\
\text { and chemical }\end{array}$ & $\begin{array}{l}\text { EXPLOSION: Steam explosion; Ammonia } \\
\text { fiber explosion (AFEX); } \mathrm{CO}_{2} \text { explosion; } \mathrm{SO}_{2} \\
\text { explosion. } \\
\text { ALKALI: Sodium hydroxide; Ammonia; } \\
\text { Ammonium sulfite. } \\
\text { GAS: Chlorine dioxide; Nitrogen dioxide } \\
\text { ACID: Sulfuric acid; Hydrochloric acid; } \\
\text { Phosphoric acid; Sulfur dioxide. } \\
\text { OXIDING AGENTS: Hydrogen peroxide; } \\
\text { Wet oxidation; Ozone. } \\
\text { CELLULOSE SOLVENTS: Cadoxen; CMCS; } \\
\text { SOLVENT EXTRACTION OF LIGNIN: } \\
\text { Ethanol-water extraction; Benzene- water } \\
\text { extraction; Ethylene-water extraction; } \\
\text { Butanol-water extraction; Swelling agents. }\end{array}$ & $\begin{array}{l}\text { Delignification; decrease } \\
\text { of cellulose crystallinity } \\
\text { and polymerization } \\
\text { degree; partial or } \\
\text { complete hemicellulose } \\
\text { hydrolysis }\end{array}$ \\
\hline Biological & Actinomycetes and Fungi & $\begin{array}{l}\text { Delignification; reduction } \\
\text { of cellulose and } \\
\text { hemicellulose } \\
\text { polymerization degree }\end{array}$ \\
\hline
\end{tabular}

Source: Taherzadeh \& Karimi, 2007.

Table 3. Pretreatment methods of lignocellulosic materials for enzymatic hydrolysis. 
to be technically and economically feasible for large scale processes. In some cases, a method is initially employed to increase the efficiency of another method to be used afterwards. Besides, it should be taken in consideration that the choice of pretreatment has to be compatible to the subsequent hydrolysis step. Hydrolysis with diluted acids (gentle acid treatments) is probably the most widely used amongst the chemical pretreatments, and it can be used for direct obtainment of fermentable sugars, originated from hemicellulose fraction or as precedent of enzymatic hydrolysis (Taherzadeh \& Karimi, 2007). One of the main advantages of this type of pretreatment is the high xylose yield, from xylan degradation, representing an important economy in the ethanol production process as a whole, given that approximately $90 \%$ of sugars from hemicellulose are this way recovered (Sun \& Cheng, 2002). However, S. cerevisiae, the most used microorganism for industrial ethanol fermentation processes, and the majority of bacteria and other yeasts do not utilize D-Xylose. Thus, there has been a great emphasis in the last two decades on developing an efficient organism for xylose fermentation through metabolic engineering (Jeffries, 2006; Martín et al., 2007a).

In the pretreatment with diluted acids, cellulose and lignin fractions remain unaltered. On the other hand, some disadvantages are the need of $\mathrm{pH}$ neutralization for the following enzymatic hydrolysis process, high maintenance cost due to corrosion problems and possible generation of cellulase activity inhibitors, furfural and other condensation products generated from the rapid xylose degradation, which should be removed through biomass washing prior to enzymatic hydrolysis (Sun \& Cheng, 2002). Cellulose, on the other hand, needs more severe hydrolysis conditions, considering its crystalline nature. Acid-catalyzed cellulose hydrolysis is a complex and heterogeneous reaction, involving physical and chemical factors following the mechanism of $\beta-1,4$ glycosydic bond cleavage (Xiang et al., 2003).

Pretreatment with diluted sulphuric acid generaly reaches high reaction rates and significantly provides celulose hydrolysis (Esteghlalian et al., 1997). In a general way, acid hydrolysis reactions may be represented by:

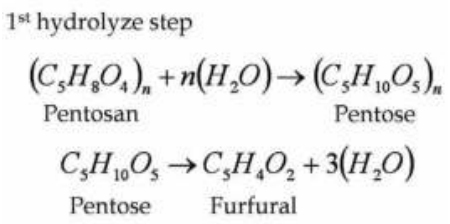

$$
\begin{aligned}
& 2^{\text {nd }} \text { hydrolyze step } \\
& \underset{\text { Pentose }}{\left(\mathrm{C}_{6} \mathrm{H}_{10} \mathrm{O}_{5}\right)_{n}+n\left(\mathrm{H}_{2} \mathrm{O}\right) \rightarrow n\left(\mathrm{C}_{6} \mathrm{H}_{12} \mathrm{O}_{6}\right)} \\
& \text { Pexose }
\end{aligned}
$$

The explosion, with or without the presence of vapor, is one of the most cited pretreatment methods for lignocellulosic biomass. Vapor explosion removes most of the hemicellulose, promotes lignin depolymerization, facilitating the access of cellulases to their substrate (Moniruzzaman, 1996) decreasing the amount of lignin available for non specific and unproductive bonding to cellulases and hemicellulases. In this method, biomass is treated with saturated vapor $\left(160-260^{\circ} \mathrm{C}\right)$ for a few seconds to minutes, under high pressure $(0.69-4.83 \mathrm{MPa})$, which is abruptly reduced to atmospheric pressure, making the material go through an explosive decompression (Varga et al., 2004). Adding $\mathrm{H}_{2} \mathrm{SO}_{4}$ (or $\mathrm{SO}_{2}$ ) or $\mathrm{CO}_{2}$ to the vapor explosion process may significantly improve enzymatic hydrolysis, decrease the formation of inhibiting compounds and promote a more complete hemicellulose removal (Morjanoff \& Gray, 1987). The advantages of vapor explosion pretreatment include the low energetic requirement, when compared to mechanical fragmentation, and the absence of environmental or recycling costs. This type 
of pretreatment is amongst the ones with lower cost for hardwood and agricultural residues (Clark \& Mackie, 1987). Disadvantages of this method include incomplete dissociation of the lignin-carbohydrates matrix and formation of compounds that may have inhibitory effect on microorganisms used during the downstream processes (microbial growth, enzymatic hydrolysis and/or fermentation) (Mackie et al., 1985), which leads to the need of washing the pretreated biomass (McMillan, 1994). Washing decreases the overall yield of the saccharification process, once it removes part of the soluble sugars generated by hemicelluloses' hydrolysis (Mes-Hartree et al., 1988).

\subsection{Enzymatic saccharification}

The enzymatic hydrolysis of lignocellulosic biomass is advantageous when compared to the chemical conversion, once there is no substrate loss due to chemical modifications and moderate and non corrosive operational conditions may be used. In addition, it provides better yields since it does not generate collateral products. During lignocellulose saccharification, the use of auxiliary enzymes such as feruloyl esterases and ligninases is interesting, given that it facilitates the access of cellulases and hemicellulases to their substrates (Sandgren et al, 2005; Selig et al., 2008). Therefore, complex enzymatic preparations are more efficient for the degradation of lignocellulosic material than those that do not have the concerted action of these enzymes (Yu et al., 2005).

The different biomass pretreatment strategies and the optimization of the enzymes production processes have resulted in several-fold reduction of enzyme loading for lignocellulose hydrolysis (Merino \& Cherry, 2007) but the efficient enzymatic conversion of cellulose and hemicellulose polymers is still the major bottleneck in the utilization of lignocellulosic residues for bioethanol production. Thus, the need of obtaining efficient enzyme mixtures, with the minimal number of key enzymatic activities, in an optimal combination is clear. Besides, the optimal reaction conditions and minimal dosage requirements must be known (Meyer et al., 2009).

With the cost reduction for enzyme production, caused by the use of alternative and inexpensive substrates such as the lignocellulosic residues or by the use of modern technologies for production optimization such as cloning and heterologous superexpression, enzymatic hydrolysis cost tends to become relatively low when compared to acid hydrolysis. Moreover, there is a possibility of recover and recycle of the enzymes bound to the residual substrate as well as the enzymes from reaction suspension.

One of the great disadvantages of the enzymatic hydrolysis of lignocellulosic material is related to the inhibition by the products of carbohydrate hydrolysis, especially when concerning enzymes from the cellulolytic complex, especially $\beta$-glucosidases, key enzymes for the complete saccharification of cellulose into glucose. The low activity of this enzyme or its inhibition by glucose $\left(K_{\mathrm{i}}\right.$ of most $\beta$-glucosidases from typical cellulase-producing microorganisms is 1-14 mmol L-1 glucose) (Yun et al., 2001; Decker et al., 2000) results in celobiose accumulation, a potent inhibitor of cellobiohydrolases and endoglucanases, decreasing hydrolysis rates (Holtzapple et al., 1990; Kovács et al., 2009). Inhibition of the cellulases by hemicellulose-derived sugars has also been shown (Xiao et al., 2004).

The addition of a surplus of $\beta$-glucosidase activity is an alternative to overcome the competitive product inhibition of the $\beta$-glucosidases. However, the use of high concentrations of this enzyme to reduce inhibition problems does not seem advantageous, once it can significantly increase process cost. Another strategy is to screen for $\beta$ - 
glucosidases with high glucose tolerance. $\beta$-glucosidases with $K_{\mathrm{i}}$ up to $1400 \mathrm{mmol} \mathrm{L-1}$ have been reported (Decker et al., 2000) and these could be cloned into the cellulase-producing microorganisms to produce a more efficient enzyme mixture. The removal of sugars during hydrolysis by ultrafiltration or by employing the simultaneous saccharification and fermentation process (SSF), where the sugars produced during enzymatic hydrolysis are simultaneously fermented to ethanol, have also been reported as alternatives to overcome the problem of enzyme inhibition by the final products of carbohydrate degradation (Sun \& Cheng, 2002; Jeffries \& Jin, 2000).

It has been shown that ethanol also inhibits cellulases, although less intensely when compared to glucose (Holtzapple et al., 1990; Chen \& Jin, 2006). Cellulases inhibition by ethanol follows a noncompetitive inhibition pattern for ethanol concentrations less than $4 \mathrm{M}$ and, when the ethanol concentration is increased, the enzyme is denatured. Ethanol also interferes with enzyme (manly cellobiohydrolases) adsorption to cellulose and modifies the cooperative effect between cellobiohydrolases and endoglucanases (Ooshima et al., 1985; Holtzapple et al., 1990).

During the pretreatment, the lignocellulose degradation products and hemicellulosederived monomeric sugars formed and released into the liquid fraction (prehydrolysate) have also been shown to inhibit enzymes activities, since the remaining solid fraction (amorphous cellulose and lignin) is absorbed with this liquid up to $60-90 \%$ of its total weight. Among these degradation products we can mention organic acids (acetic acid, formic acid, and levulinic acid), sugar degradation products (furfural from xylose and 5hydroxymethylfurfural - HMF - from hexoses at high temperature and pressure) and lignin degradation products (vanillin, syringaldehyde, and 4-hydroxybenzalde-hyde) (Palmqvist et al., 1999a; Cantarella et al., 2004). However, the inhibition of enzymatic hydrolysis by these products has not been clearly elucidated (Jorgensen et al., 2007). It has been shown that washing the pretreated material results in faster conversion of cellulose due to removal of inhibitors (Tengborg et al., 2001). Ultrafiltration has also been used to remove sugars and other small compounds that may inhibit the action of the enzymes.

Another obstacle to enzymatic hydrolysis of lignocellulose carbohydrates is the possibility of unspecific adsorption of enzymes (both cellulases and hemicellulases) onto lignin particles or surfaces, mainly due to hydrophobic interaction and, possibly, due to ionic-type lignin-enzyme interaction. Actually, after almost complete hydrolysis of the cellulose fraction in lignocellulosic material, up to $60-70 \%$ of the total enzyme added can be bound to lignin (Lu et al., 2002). Therefore, cellulases with lower affinity for lignin could be explored in the development of new enzymatic complexes preparations (Berlin et al., 2005; Palonen et al., 2004).

The trouble of unspecific enzymes adsorption to lignin could be overcome by the addition of non-ionic surfactants like Tween 20 or Tween 80 . It could also improve the hydrolysis rate so that the same degree of conversion can be obtained at lower enzyme loadings.106. Ethylene oxide polymers such as poly(ethylene glycol) (PEG) show a similar effect and it is advantageous due to its low cost (Kristensen et al., 2007). Besides the use of surfactants, other methods for desorbing enzymes have been developed, such as use of alkali, urea and buffers of varying $\mathrm{pH}$ (Otter et al., 1989).

As previously mentioned, recycling of the enzymes from the reaction suspension as well as from the residual substrates is an attractive way of reducing costs for enzymatic hydrolysis (Qi et al., 2011). The addition of fresh substrate could recover free cellulases in bulk solution 
by adsorption, due to the high affinity of these enzymes for cellulose (Castanon \& Wilke, 1980). The new material retaining up to $85 \%$ of the enzyme activity free solution could then be separated and hydrolyzed in fresh media eventually with supplementation of more enzyme (Tu et al., 2007). Since $\beta$-glucosidase does not typically bind to the cellulosic substrate it cannot be reused and supplementation with this enzyme is required at the beginning of each round of hydrolysis in order to avoid the buildup of cellobiose and the subsequent end-product inhibition of cellulase (Lee etal., 1995; Tu et al., 2007).

Ultrafiltration has been cited as viable process capable of recovering all of enzyme components (endoglucanase, exoglucanase and $\beta$-glucosidase) after complete hydrolysis of the cellulose (Mores et al., 2001; Qi et al., 2011). Depending on the lignin content of the substrate, only up to $50 \%$ of the cellulases can be recycled using this approach. The saving is therefore low, taking into account recovery costs (Singh et al., 1991; Lee et al., 1995).

The denaturation or loss of enzyme activity due to mechanical shear, proteolytic activity or low thermostability should also be considered as limiting factors for hydrolysis. Besides, due to cellobiohydrolases processivity and strong binding to cellulose chain (by the catalytic site) obstacles can make the enzymes halt and become unproductively bound. Summarizes the factors that limit efficient cellulose hydrolysis (Jorgensen et al., 2007).

The range of toxic compounds generated during some types of pretreatment and hydrolysis of lignocellulosic materials, mainly with high temperature and pressure, under acidic conditions, can limit the rapid and efficient fermentation of the hydrolysates by the fermenting microorganisms, such as Saccharomyces cerevisiae. The inhibiting compounds are divided in three main groups based on origin: weak acids, furan derivatives and phenolic compounds. As mentioned above, furfural and HMF are formed from xylose and hexoses respectively and when they are broken down, they generate formic acid. HMF degradation also yields levulinic acid. Besides, the partial lignin breakdown generates phenolic compounds (Palmqvist \& Han-Hagerdal, 2000).

Undissociated weak acids inhibit cell growth since they are liposoluble when undissociated and can diffuse across the plasma membrane. In the cytosol, dissociation of the acid occurs due to the neutral intracellular $\mathrm{pH}$, thus decreasing the cytosolic $\mathrm{pH}$ (Pampulha \&LoureiroDias, 1989) and cell viability. According to Verduyn et al. (1990), when fermentation $\mathrm{pH}$ is low, cell proliferation and viability are inhibited also in the absence of weak acids, due to the increased proton gradient across the plasma membrane, resulting in an increase in the passive proton uptake rate.

Studies have been reported that furfural is metabolized by $S$. cerevisiae under aerobic, oxygen-limiting and anaerobic conditions (Taherzadeh et al., 1998; Navarro, 1994; Palmqvist et al., 1999b). Furfural is reduced to furfuryl alcohol during fermentation, with high yields, and the reduction increases with the increasing of inoculum size and of specific growth rate in chemostat (Fireoved \& Mutharasan, 1986) and batch cultures (Taherzadeh et al., 1998). At high furfural concentrations (above $84 \mathrm{mmol}_{\mathrm{g}}{ }^{-1}$ ) the reduction rate decreases in anaerobic batch fermentation, probably due to cell death (Palmqvist et al., 1999b). Aerobic growth is less sensible to inhibition by furfuryl alcohol in S. cerevisiae than in Pichia stipitis (Weigert et al., 1988; Palmqvist et al., 1999b). According to Palmqvist et al. (1999a) growth is more sensitive to furfural than is ethanol production. Indeed, at low concentrations of furfural (approximately $29 \mathrm{mmol} / \mathrm{L}$ ) there is an invrease in ethanol yield. The authors reported that this probably occurs because the reduction of furfural to furfuryl alcohol, by NADHdependent yeast dehydrogenases (which regenerates $\mathrm{NAD}^{+}$) has a higher priority than the 
reduction of dihydroxyacetone phosphate to glycerol (which regenerates NADH). Thus the lower carbon consumption for glycerol production leads to an increase in ethanol yield.

Cell integrity is harmed by phenolic compounds, especially those of low molecular weight, since they affect the membrane ability to act as selective barrier and enzyme matrice (Heipieper et al., 1994). These compounds have a considerable inhibitory effect during the fermentation of lignocellulosic hydrolysates, by a not elucidated mechanism (Delgenes et al., 1996).

Another obstacle for the efficient enzymatic saccharification of lignocellulosic material is related to the cellulase recycling (turnover), since the absorption characteristics of these enzymes on lignocellulosic substrates have not yet been completely understood. The enzymatic degradation of cellulose is a complex process that occurs at the limit of solid/liquid phases, where the enzymes are the mobile components. When the cellulases act in vitro on the insoluble substrate, three processes occur simultaneously: (a) physical and chemical changes of cellulase at the solid phase (still not solubilized); (b) primary hydrolysis, involving the liberation of soluble intermediates from the surface of cellulose molecules that are in reaction and (c) secondary hydrolysis, involving the hydrolysis of soluble intermediates into others of low molecular weight and, finally, into glucose (MOISER; LADISCH; LADISCH, 2002).

In a general way, enzymatic hydrolysis rate of the lignocellulosic material rapidly decreases, with cellulose enzymatic degradation being characterized by a fast initial phase, followed by a slow secondary phase, which can last until all the substrate is degradated. This has been frequently explained by the rapid hydrolysis of the easily accessible cellulosic fraction, by strong enzyme inhibition, especially $\beta$-glucosidases, by the product and the low inactivation of absorbed enzyme molecules (Balat et al., 2008).

Cellulose is an insoluble substrate; the adsorption of the cellulases onto the cellulose surface is the first step in the initiation of hydrolysis. Therefore, the presence of CBMs is essential for fast and correct docking of the cellulases on the cellulose. Removal of CBMs significantly lowers the hydrolysis rate on cellulose (Suurnäkki et al., 2000).

\section{Stratagies for second generation ethanol production}

Saccharification of lignollulosic material and the conversion of sugars into ethanol may employ different strategies, carried out simultaneously or sequentially. In all cases, the pretreatment stage is of crucial importance to increase enzymatic conversion efficiency.

When enzymatic hydrolysis and alcoholic fermentation are carried out separately, the process is known as Separate (or Sequencial) Hydrolysis and Fermentation (SHF). In this case, the enzymatic hydrolysis of the carbohydrates and the subsequent fermentation of hexoses and pentoses are carried out in distinct reactors and they can be performed under their optimum conditions, which is an advantage of this strategy. However, SHF leads to the accumulation of the glucose derived from the hydrolysis of cellulose that can inhibit cellulases, affecting the reaction rates and yields. Besides, part of glucose is adsorbed in the solid residual material, lowering the sugar conversion (Soccol et al., 2010; Olofsson et al., 2008).

Enzymatic hydrolysis and sugar fermentation can run together, in a same reactor, as Simultaneous Saccharification and Fermentation (SSF), is faster and presents a low cost process since only one reactor is necessary and the glucose formed is simultaneously 
fermented to ethanol, which also avoid the problem of product inhibition associated with enzymes. The risk of contamination is lower due to the presence of ethanol, the anaerobic conditions and the continuous withdrawal of glucose. Pentoses fermentation can be performed in a separate reactor. One disadvantage of this strategy is relates to the different optimum temperature for enzymatic hydrolysis $\left(45-50{ }^{\circ} \mathrm{C}\right)$ and alcoholic fermentation $(28$ $\left.35^{\circ} \mathrm{C}\right)$ (Soccol et al., 2010).

The process called Simultaneous Saccharification and Co Fermentation SSCF, pentoses and hexoses conversion are carried out in the same reactor (Castro; Pereira Jr, 2010). Finally, in the Consolidated BioProcessing (CBP) a single microbial community produced all the required enzymes and converts sugars into ethanol in a single reactor (Lynd, 1996), lowering overall costs. Studies suggest that CBP may be feasible and the researches have focused on the development of new microorganisms adapted to this process, which has been a key challenge (Lynd et al., 2002).

\section{Conclusions}

The search for "clean technologies", using alternative feedstocks, in order to obtain products of industrial interest, save energy and reduce effluent production is economically advantageous and has been encouraged by environmental issues during the last years. Researches dealing with the use of lignocellulosic wastes in bioprocesses, specially for microorganisms cultivation and cellulases, xylanases, ligninases and other enzymes production, stand out. These enzymes have potential for various biotechnological applications and in recent years special attention has been given to the destructuring, hydrolysis and saccharification of lignocellulosic material in order to obtain fermentable sugars that can be converted into second generation ethanol by fermenting microorganisms. However, for an efficient conversion of lignocellulosic materials into products of industrial interest, some bottlenecks must be overcome. The search for microbial strains suitable for cultivation in large scale, producing enzymes with characteristics appropriate to the biotechnological processes to which they are intended is of great importance.

\section{References}

Abrahão, M.C.; Gugliotta, A.M.; Da Silva, R.; Fujieda, R.J.Y.; Boscolo, M. \& Gomes, E. (2008). Ligninolytic Activity from Newly Isolated Basidiomycete Strains and Effect of These Enzymes on the Azo Dye Orange II Decolourisation. Annals of Microbiology, Vol.58, No.3, (May 2008), pp. 427-432, ISSN 1590-4261.

Alves, A. M. C. R.; Record, E.; Lomascolo, A.; Scholtmeijer, K.; Asther, M.; Wessels, J. G. H. \& Woesten, H.A.B. (2004). Highly Efficient Production of Laccase by the Basidiomycete Pycnoporus cinnabarinus. Applied and Environmental Microbiology, Vol. 70, No 11, (November 2004), pp. 6379-6384, ISSN: 0099-2240.

Alves-Prado, H.F.; Pavezzi, F.C.; Leite, R.S.R.; Oliveira, V.M.; Sette, L.D. \& Da Silva, R. (2010). Screening and Production Study of Microbial Xylanase Producers from Brazilian Cerrado. Applied Biochemistry and Biotechnology, Vol.161, No.1-8, (November 2009), pp. 333-346, ISSN 0273-2289. 
Arantes, V. \& Saddler, J.N. (2010). Access to Cellulose Limits the Efficiency of Enzymatic Hydrolysis: The Role of Amorphogenesis. Biotechnology for Biofuels, Vol.3, No.4, (February 2010), pp.1-11, ISSN 1754-6834.

Aro, N.; Pakula, T. \& Penttila, M. (2005). Transcriptional Regulation of Plant Cell Wall Degradation by filamentous Fungi. FEMS Microbiology Reviews, Vol.29, No.4, (September 2005), pp. 719-739, SSN:0168-6445.

Aspinall, G. O. (1959). Structural Chemistry of the Hemicelluloses. Advances Carbohydrate Chemistry, Vol.14, pp. 429-468.

Badhan, A.K.;Chadha, B.S.; Kaur, J.; Saini, H.S.; Bhat, M.K. (2007) Production of Multiple Xylanolytic and Cellulolytic Enzymes by Thermophilic Fungus Myceliophthora sp. IMI 387099. Bioresource Technology, Vol.98, No.3, (February 2007), pp. 504-510, ISSN:0960-8524.

Balat, M.; Balat, H. \& Öz, C. (2008). Progress in Bioethanol Processing. Progress in Energy and Combustion Science, Vol.34, No.5, (October 2008), pp. 551-573, ISSN 0360-1285.

Baldrian, P. (2006). Fungal Laccases - Occurrence and Properties. FEMS Microbiology Reviews, Vol.30, No.2, (March 2006), pp. 215-242, ISSN 1574-6976.

Barry, V. \& Dillon, T. (1940). Occurence of Xylans in Marine Algae. Nature, Vol.146, (November 1940), pp. 620-620, ISSN 0028-0836.

Bayer, E.A.; Belaich, J.P.; Shoham, Y. \& Lamed, R. (2004). The Cellulosomes: Multienzyme Machines for Degradation of Plant Cell Wall Polysaccharides. Annual Review of Microbiology, Vol.58, (June 2004), pp. 521-554, ISSN 0066-4227.

Bayer, E.A.; Shimon, L.J.W.; Shoham, Y. \& Lamed, R. (1998). Cellulosomes-Structure and Ultrastructure. Journal of Structural Biology, Vol.124, No.2-3, (December 1998), pp. 221-234, ISSN 1047-8477.

Beg, Q.K.; Kapoor, M.; Mahajan, L. \& Hoondal, G.S. (2001). Microbial Xylanases and their Industrial Applications: A Review. Applied Microbiology and Biotechnology, Vol.56, No.3-4, (August 2001), pp. 326-338, ISSN 1432-0614.

Berlin, A.; Gilkes, N.; Kurabi, A.; Bura, R.; Tu, M.; Kilburn, D. \& Saddler J. (2005) Weak Lignin-Binding Enzymes - A Novel Approach to Improve Activity of Cellulases for Hydrolysis of Lignocellulosics. Applied Biochemistry and Biotechnology, Vol.121, No.1-3, pp. 163-170, ISSN 0273-2289.

Bhattacharya, S.S.,Garlapati, V.K. \& Banerjee, R. (2011). Optimization of Laccase Production Using Response Surface Methodology Coupled With Differential Evolution. New Biotechnology, Vol. 28, No.1, (January 2011),pp 31-39, ISSN:1871-6784..

Bianchi, V.L.D.; Moraes, I.O. \& Capalbo, D.M.F. (2011). Fermentação em estado sólido. In: Biotecnologia industrial. São Paulo, Edgard Blücher, v. 2, cap. 13, 247-276, 2001.

Bidlack, J.; Malone, M. \& Benson, R. (1992). Molecular Structure and Component Integration of Secondary Cell Walls in Plants. Proceedings of the Oklahoma Academy of Science, Vol.72, pp. 51-56, ISSN 0078-4303.

Binod, P.; Sindhu, R.; Singhania, R.R.; Vikram, S.; Devi, L.; Nagalakshmi, S.; Kurien, N.; Sukumaran, R.K. \& Pandey, A. (2010). Bioethanol Production from Rice Straw: An Overview. Bioresource Technology, Vol.101, No.13, (July 2010), pp. 4767-4774, ISSN 0960-8524.

Bobbio, F.O. \& Bobbio, P. A. (2003). Carboidratos. In: Química do Processamento de Alimentos, Varela, cap. 1, p. 69. 
Bocchini, D.A.; Damiano, V.B.; Gomes, E. \& Da Silva, R. (2003). Effect of Bacillus circulans D1 Thermostable Xylanase on Biobleaching of Eucalyptus Kraft Pulp. Applied Biochemistry and Biotechnology, Vol. 105, No. 1-3, pp. 393-401, ISSN 0273-2289.

Boisset, C.; Chanzy, H.; Henrissat, B.; Lamed, R.; Shoham, Y. \& Bayer, E.A. (1999). Digestion of Crystalline Cellulose Substrates by the Clostridium Thermocellum Cellulosome: Structural and Morphological Aspects. Biochemical Journal, Vol.340, No.3, (June 1999), pp. 829-835, ISSN 0264-6021.

Bon, E.P.S.; Gírio, F. \& Pereira Jr, N. (2008). Enzimas na Produção de Etanol. In: Enzimas Em Biotecnologia. Produção, Aplicações E Mercado. Bom, E.; Ferrara, M.A. \& Corvo, M.L., PP 241-271, Interciência, ISBN: 978-85-7193-189-3, , Rio de Janeiro.

Boraston, A.B.; Bolam, D.N.; Gilbert, H.J. \& Davies, G.J. (2004). Carbohydrate-Binding Modules: F ne-Tuning Polysaccharide Recognition. Biochemical Journal, Vol.382, No.3, (September 2004), pp. 769-781, ISSN 0264-6021.

Brown, R.M.; Saxena, I.M. \& Kudlicka, K. (1996).Cellulose Biosynthesis in Higher Plants. Trends in Plant Science, Vol.1, No.5, pp. 149-156, ISSN 1360-1385.

Buaban, B.; Inoue, H.; Yano, S.; Tanapongpipat, S.; Ruanglek, V.; Champreda, V.; Pichyangkura, R.; Rengpipat, S. \& Eurwilaichitr, L. (2010). Bioethanol Production From Ball Milled Bagasse Using An On-Site Produced Fungal Enzyme Cocktail And Xylose-Fermenting Pichia Stipitis. Journal Bioscience Bioengineering, Vol.110, No.1, (July 2010), pp. 18-25, ISSN 1389-1723.

Buanafina, M.M.O. (2009). Feruloylation in Grasses: Current and Future Perspectives. Molecular Plant, Vol.2, No.5, (August 2009), pp. 861-872, ISSN 1674-2052.

Cantarella, M.; Cantarella, L.; Gallifuoco, A.; Spera, A. \& Alfani, F. (2004) Effect of Inhibitors Released During Steam Explosion Treatment of Poplar Wood on Subsequent Enzymatic Hydrolysis and SSF. Biotechnology Progress, Vol.20, No.1, (July 2003), pp. 200-206, ISSN:8756-7938.

Castanon, M. \& Wilke, C.R., (1980). Adsorption and Recovery of Cellulases During Hydrolysis of Newspaper. Biotechnology Bioengineering, Vol.22, No.5, (May 1980), pp. 1037-1053, ISSN 1097-0290.

Castro, A. \& Pereira Jr, N. (2010). Produção, Propriedades e Aplicação de Celulases na Hidrólise de Resíduos Agroindustriais. Quimica. Nova, Vol.33, No.1, (November 2009), pp. 181-188, ISSN 0100-4042.

Cerqueira Leite, R.C.; Leal, M.R.L.V.; Cortez, L.A.B.; Griffin, W.M. \& Scandiffio, M.I.G. (2009). Can Brazil Replace 5\% of the 2025 Gasoline World Demand With Ethanol? Energy, Vol.34, No.5, (May 2009), pp. 655-661, ISSN 0360-5442.

Chanda, S.K.; Hirst, E.L.; Jones, J.K.N. \& Percival, E.G.V. (1950). 262. The Constitution of Xylan from Esparto Grass (Stipa Tenacissima, L.). Journal of the Chemical Society, Vol.50, pp. 1287-1289, ISSN 0022-4936.

Chandel, A.K.; Es, C.; Rudravaram, R.; Narasu, M.L.; Rao, L.V. \& Ravindra, P. (2007) Economics and environmental impact of bioethanol production technologies: an appraisal. Biotechnology and Molecular Biology Reviews, Vol.2, pp.14-32, SSN:1538-2273.

Chang, V.S.; Holtzapple, M.T. (2000). Fundamental Factors Affecting Biomass Enzymatic Reactivity. Applied Biochemistry and Biotechnology, Vol.84, pp. 5-37, SSN:0273-2289.

Chávez, R.; Bull, P. \& Eyzaguirre, J. (2006). The Xylanolytic Enzyme System from the Genus Penicillium. Journal of Biotechnology, Vol.123, No.4, (June 2006), pp. 413-433, ISSN:1462-0316. 
Chen, H. \& Jin, S. (2006). Effect of Ethanol and Yeast on Cellulase Activity and Hydrolysis of Crystalline Cellulose. Enzyme and Microbial Technology, Vol.39, No.7, (November 2006), pp. 1430-1432, ISSN 0141-0229.

Christov, L.P. \& Prior, B.A. (1993) Esterases of Xylan-Degrading Microorganisms, Production, Properties and Significance. Enzyme and Microbial Technology, Vol.15, No.6, (June 1993), pp. 460-475, ISSN 0141-0229.

Clark, T.A. \& Mackie, K.L. (1987) Steam Explosion of the Soft-Wood Pinus Radiata With Sulphur Dioxide Addition. I. Process Optimization. Journal of Wood Chemistry and Technology, Vol.7, No.3, pp. 373-403, ISSN:0277-3813

Collins, T.; Gerday, C. \& Feller, G. (2005). Xylanases, Xylanase Families and Extremophilic Xylanases. FEMS Microbiology Reviews, Vol.29, No.1, (January 2005), pp. 03-23, ISSN 1574-6976.

Conessa, A.; Punt, P. J. \& Van Den Hondel, C. A. (2002). Fungal Peroxidases: Molecular Aspects and Applications. Journal of Biotechnology, Vol.93, No.2, (February 2002), pp. 143-158, ISSN: 0168-1656.

Coughlan, M P. \& Ljungdahl, L. G. (1988). Comparative Biochemistry of Fungal and Bacterial Cellulolytic Enzyme Systems. FEMS Symposium, Vol. 3 (Biochem. Genet. Cellul. Degrad.), pp. 11-30, ISSN:0163-9188.

Coughlan, M.P. (1992). Towards an Understanding of the Mechanism of Action of Main Chain Cleaving Xylanases. In: Xylans And Xylanases, Visser, J., pp. 111-139, Elsevier ISSN:0921-0423, Amsterdan.

Dashtban, M.; Schraft, H. \& Qin, W. (2009). Fungal Bioconversion of Lignocellulosic Residues; Opportunities \& Perspectives. Internetional Journal of Biological Sciences, Vol.5, No.6, (September 2009), pp. 578-595, ISSN 1449-2288.

Dawson, L. \& Boopathy, R. (2007). Use of Post-Harvest Sugarcane Residue for Ethanol Production. Bioresource Technology, Vol. 98, No.9, (August 2006), pp. 1695-1699, ISSN:0960-8524.

Decker, C.H.; Visser, J. \& Schreier, P. (2000). B-Glucosidases from Fve Black Aspergillus Species: Study of Their Physico-Chemical and Biocatalytic Properties. Journal of Agricultural and Food Chemistry Vol.48, No.10, (October 2000), pp. 4929-4936, ISSN 0021-8561.

Delgenes, J.P.; Moletta, R. \& Navarro, J.M. (1996). Effects of Lignocellulose Degradation Products on Ethanol Fermentations of Glucose and Xylose by Saccharomyces Cerevisiae, Pichia Stipitis, and Candida Shehatae. Enzyme and Microbial Technology, Vol.19, No.3, (August 1996), pp. 220-225, ISSN 0141-0229.

Demirbas, A. (2008). Products from Lignocellulosic Materials via Degradation Processes. Energy Sources, Vol.30, No.1, (January 2008), pp. 27-37, ISSN 1521-0510.

Dey, P.M. \& Brinson, K. (1984). Plant Cell Walls. Advances in Carbohydrate Chemistry and Biochemistry, Vol.42, pp. 265-294, ISSN:0065-2318

Durán, N. \& Esposito, E. (2000). Potential Application of Oxidative Enzymes and Phenoloxidase-like Compounds in Wastewater and Soil Treatment: a Review. Applied Catalysis B: Environmental, Vol.28, No.2, (November 2000), pp. 83-99, ISSN: 0926-3373.

Ebringerová, A.; Hromadkova, Z. \& Heinze, T. (2005). Hemicellulose. Advances in Polymer Sciences, Vol.186 (Polisaccharides I), pp. 1-67, ISSN:0065-3195.

Eda, S.; Ohnishi, A. \& Kato, K. (1976). Studies on the chemical structure of tobacco hemicellulose. Part I. Xylan Isolated from the Stalks of Nicotiana Tabacum. 
Agricultural and Biological Chemistry., Vol.40, No.2, (September 1975), pp. 359-364, ISSN:0002-1369.

Elegir, G., Sykes, M. \& Jeffries, T.W. (1995). Differential and Synergistic Action of Streptomyces Endoxylanaes in Prebleaching of Kraft Pulp. Enzyme and Microbial Technology, Vol.17, No.10, (October 1995), pp. 954-959, ISSN:0141-0229.

Esteghlalian, A.; Hashimoto, A.G.; Fenske, J.J. \& Penner, M.H. (1997). Modeling and Optimization of the Dilute-Sulfuric-Acid Pretreatment of Corn Stover, Poplar and Switchhgrass. Bioresource Technology, Vol. 59, No.2-3, pp. 129-136, ISSN:0960-8524

Fang, T.J.; Liao, B.C. \& Lee, S.C. (2009). Enhanced Production of Xylanase by Aspergillus carneus M34 in Solid-State Fermentation With Agricultural Waste Using Statistical Approach. New Biotechnology, Vol.27, No.1, (February 2010), pp25-32, ISSN:1871-6784.

Fanutti, C.; Ponyi, T.; Black, G.W.; Hazlewood, G.P. \& Gilbert, H.J. (1995). The Conserved Noncatalytic 40-Residue Sequence in Cellulases and Hemicellulases from Anaerobic Fungi Functions as a Protein Docking Domain. The Journal of Biological Chemistry, Vol.270, No.49, (December 1995), pp. 29314-29322, ISSN 0021-9258

Ferraz, A.; Cordova, A. \& Machuca, A. (2003). Wood Biodegradation And Enzyme Production by Ceriporiopsis subvermispora During Solid-State Fermentation of Eucalyptus Grandis. Enzyme And Microbial Technology, Vol.32, No.1, (January 2003), pp. 59-65, ISSN:0141-0229

Ferreira-Leitão, V.; Gottschalk, L.M.F.; Ferrara, M.A.; Nepomuceno, A.L.; Molinari, H.B.C; \& Bom, E.P.S. (2010). Biomass Residues in Brazil: Availability and Potential Uses. Waste and Biomass Valorization Vol. 1, No.1, (February 2010), pp. 65-76, ISSN 1877-2641.

Festucci-Buselli; R.A.; Otoni, W.C. \& Joshi, C.P. (2007), Structure, organization, and functions of cellulose synthase complexes in higher plants. Brazilian Journal of Plant Physiology, Vol.19, No.1, (May 2007), pp. 1-13, ISSN 1677-0420.

Fireoved, R.I.,Mutharasan, R., (1986). Effect of Furfural and Ethanol on the Growth and Energetics of Yeast under Microaerobic Conditions. Annals of the New York Academy of Sciences, Vol.469, (May 1986), pp.433-447, ISSN 0077-8923.

Fontes, C.M. \& Gilbert, H.J. (2010). Cellulosomes: Highly Efficient Nanomachines Designed to Deconstruct Plant Cell Wall Complex Carbohydrates. Annual Review of Biochemistry, Vol.79, (July 2010), pp. 655-81, ISSN 0066-4154.

Freudenberg, K. (1965) Lignin: Its Constitution and Formation from P-Hydroxycinnamyl Alcohols. Science, Vol.148, No.3670, (April 1965), pp. 595-600, ISSN 0036-8075.

Fujian, X.; Hongzhang, C. \& Zuohu, L. (2001). Solid-State Production of Lignin Peroxidase (Lip) And Manganese Peroxidase (Mnp) By Phanerochaete chrysosporium Using Steam-Exploded Straw As Substrate. Bioresource Technology, Vol.80, No.2, (November 2001), pp. 149-151, ISSN:0960-8524.

Gamez, S.; Gonzalez-Cabriales, J. J.; Ramirez, J. A. \& Garrote, G. (2006). Study Of The Hydrolysis Of Sugar Cane Bagasse Using Phosphoric Acid. Journal of Food Engeneering, Vol.74, No.1, (May 2006), pp. 78-88, SSN:0260-8774.

Gao, J.; Weng, H.; Zhu, D.; Yuan, M.; Guan, F. \& Xi, Y. (2008). Production and Characterization of Cellulolytic Enzymes from the Thermoacidophlilic Fungal Aspergillus Terreus M11 under Solid-State Cultivation of Corn Stover. Bioresource Technology, Vol.99, No.16, (November 2008), pp. 7623- 7629, ISSN 09608524.

Gírio, F.M.; Fonseca, C.; Carvalheiro, F.; Duarte, L.C.; Marques, S. \& Bogel-Łukasik, R. (2010) Hemicelluloses for Fuel Ethanol: A Review. Bioresource Technology, Vol.101, No.13, (July 2010), pp. 4775-4800, ISSN 09608524. 
Glazer, A.N., Nikaido, H. (2007). Biomass, In: Microbial Biotechnology: Fundamentals of Applied Microbiology, Glazer, A.N., Nikaido, H., pp. 430-455, Cambridge University Press, ISBN 978-0-521-84210-5, New York.

Goldemberg, J. \& Guardabassi, P. (2010). Ethanol: Can The Success Of Brazil Be Replicated? Biofuels, Vol.1, No.5 (September 2010), pp. 663-665, ISSN:1759-7269.

Goldemberg, J.; Coelho, S.T. \& Guardabassi, P. (2008). The Sustainability of Ethanol Production from Sugarcane. Energy Policy, Vol, 36, No.6, (June 2008), pp. 20862097, ISSN 0301-4215.

Gomes, E.; Aguiar, A.P.; Carvalho, C.C.; Bonfá, M.R.B.; Da Silva, R. \& Boscolo, M. (2009). Ligninases Production by Basidiomycetes Strains on Lignocellulosic Agricultural Residues and their Application in the Decolorization of Synthetic Dyes. Brazilian Journal of Microbiology, Vol.40, No.1, (March 2009), pp. 31-39, ISSN 1517-8382.

Gopalakrishnan, K.; Kim, S. \& Ceylan, H. (2010). Lignin recovery and utilization. Bioenergy and Biofuel from Biowastes and Biomass, American Society of Civil Engineers, Reston, Va, pp. 247-274, ISBN: 978-0-7844-1089-9.

Gould, J.M. (1984). Alkaline Peroxide Delignification of Agricultural Residues to Enhance Enzymatic Saccharification. Biotechnology and Bioengeneering, Vol. 26, pp. 46-52, ISSN 0006-3592.

Graminha, E.B.N.; Gonçalves, A.Z.L.; Pirota, R.D.P.B.; Balsalobre, M.A.A.; Da Silva, R.; Gomes, E. (2008). Enzyme Production by Solid-State Fermentation: Application to Animal Nutrition. Animal Feed Science Technology, Vol. 144, pp. 1- 22, ISSN 03778401.

Hamelinck, C.N., Hooijdonk, G., Faaij, A.P.C. (2005). Ethanol from Lignocellulosic Biomass: Techno-Economic Performance in Short-, Midlle- and Long-Term. Biomass Bioenergy, Vol. 28, pp. 384-410, ISSN 0961-9534.

Hammel, K. E.; Cullen, D. (2008) Role of Fungal Peroxidase in Biological Lignolysis. Current Opinion Plant Biology, Vol. 11, pp. 349-355, ISSN 1369-5266.

Hartley, R. D. (1973). Lignin-carbohydrate linkages in plant cell walls. I. Carbohydrate esters of ferulic acid as components of cell walls of Lolium multiflorum. Phytochemistry, Vol.12, No. 3, (March 1973), pp. 661-665. ISSN:0031-9422.

Hatfield, R.D; Marita, J.M. \& Frost, K. (2008). Characterization of P-Coumarate Accumulation, P-Coumaroyl Transferase, and Cell Wall Changes During the Development of Corn Stems. Journal of Science Food and Agriculture, Vol. 88, No. 14, november 2008, pp. 2529-2537, ISSN 0022-5142.

Hebeish, A., Hashem, M., Shaker, N., Ramadan, M., El-Sadek, B., Hady, M.A. (2009) Effect of Post- and Pre-Crosslinking of Cotton Fabrics on the Efficiency of Biofinishing with Cellulase Enzyme. Carbohydrate Polymer, Vol. 78, pp. 953-960, ISSN 0144-8617.

Heipieper, H.J.; Weber, F.J.; Sikkema, J.; Kewelo, H. \& De Bont, J.A.M., (1994). Mechanism of Resistance of Whole Cells to Toxicorganic Solvents. Trends in Biotechnology, Vol.12, No. 10, (October 1994), pp. 409-415, ISSN 0167-7799.

Higuchi, T. (2004). Microbial Degradation of Lignin: Role of Lignin Peroxidase, Manganese Peroxidase, and Laccase. Proceedings of the Japan Academy Series B - Physical and Biological Sciences, Vol. 80, pp. 204-213, ISSN: 0386-2208.

Hölker, U.; Lenz, J. (2005). Solid-State Fermentation - Are There Any Biotechnological Advantages? Current Opinion Microbiology, Vol. 8, pp. 301-306, ISSN 1369-5274. 
Holtzapple, M.; Cognata, M.; Shu, Y.; Hendrickson, C. (1990). Inhibition of Trichoderma reesei Cellulase by Sugars and Solvents. Biotechnology and Bioengineering, Vol. 36, pp. 275287, ISSN 0006-3592.

Howard, R.L.; Abotsi, E.; Jansen Van Rensburg, E.L.; Howard S. (2003). Lignocellulose Biotechnology: Issues of Bioconversion and Enzyme Production. African Journal of Biotechnology, Vol. 2, pp. 602-619, ISSN 1684-5315.

Hsu, T.A.; Ladisch, M.R.; Tsao, G.T. (1980). Alcohol From Cellulose. CHEMTECH, Vol. 10, pp. 315- 319, ISSN 0009-2703.

Jecu, L. (2000). Solid State Fermentation of Agricultural Wastes for Endoglucanase Production. Industrial Crops and Products, Vol. 11, pp. 1-5, ISSN 0926-6690.

Jeffries, T.W. (2006). Engineering Yeasts for Xylose Metabolism. Current Opinion Biotechnology, Vol. 17, pp. 1-7, ISSN 0958-1669.

Jeffries, T.W.; Jin, Y.S. (2000). Ethanol and Thermotolerance in the Bioconversion of Xylose by Yeasts. Advances in Applied Microbiology, Vol. 47, pp. 221- 268, ISSN 0065-2164.

Johnson, E.A.; Madia, A.; Demain, A.L. (1981). Chemically Defined Minimal Medium for the Growth of the Anaerobic Cellulolytic Thermophile Clostridium thermocellum. Applied and Environmental Microbiology, Vol. 41, pp. 1060-1062, ISSN 0099-2240.

Johnson, E.A.; Sakajoh, M.; Halliwell, G.; Madia, A.; Demain, A.L. (1982). Saccharification of Complex Cellulosic Substrates by the Cellulase System from Clostridium thermocellum. Applied and Environmental Microbiology, Vol. 43, pp. 1125-32, ISSN 0099-2240.

Jørgensen, H.; Kristensen, J.B.; Felby, C. (2007). Enzymatic Conversion of Lignocellulose into Fermentable Sugars: Challenges and Opportunities. Biofuels Bioproducts and Biorefining-Biofpr. Vol. 1, pp. 119-134, ISSN 1932-104X.

Kang, W.; Park, Y.S.; Lee, J.S.; Hong, S.I.; Kim, S.W. (2004). Production of Cellulases and Hemicellulases by Aspergillus niger KK2 from Lignocellulosic Biomass. Bioresource Technology, Vol. 91, pp. 153-156, ISSN 0960-8524.

Khanahmadi, M.; Mitchell, D.A.; Beheshti, M.; Roostaazad, R. \& Sanchez, R.L. (2006). Continuous Solid-State Fermentation as Affected by Substrate Flow Pattern. Chemical Engineering Science, Vol. 61, No. 8, april 2006, pp. 2675-2687, ISSN 00092509.

Kim, S.; Dale, B.E. (2004). Global Potential Bioethanol Production from Wasted Crops and Crop Residues. Biomass and Bioenergy, Vol. 26, pp. 361 - 375, ISSN 0961-9534.

Kondo, T.; Mizuno, K.; Kato, T. (1990). Cell Wall-Bound p-Coumaric Acids in Italian Ryegrass. Canadian Journal of Plant Science, Vol. 71, pp. 495-499, ISSN: 0008-4220.

Kovács, K.; Szakacs, G.; Zacchi, G. (2009). Comparative Enzymatic Hydrolysis of Pretreated Spruce by Supernatants, Whole Fermentation Broths and Washed Mycelia of Trichoderma reesei and Trichoderma atroviride. Bioresource Technology, Vol. 100, pp. 1350-1357, ISSN 0960-8524.

Koyama, M.; Helbert, W.; Imai, T.; Sugiyama, J.; Henrissat, B. (1997). Parallel-Up Structure Evidences the Molecular Directionality During Biosynthesis of Bacterial Cellulose. Proceedings of the National Academy of Sciences of the United States of America, Vol. 94, pp. 9091-9095, ISSN 0027-8424.

Krishna, S. H.; Chowdary, G. V. (2005). Optimization of Simultaneous Saccharification and Fermentation for the Production of Ethanol from Lignocellulosic Biomass. Journal Agricultural of Food Chemistry, Vol. 48, pp. 1971-1976, ISSN 0021-8561. 
Kristensen, J.B.; Börjesson, J.; Bruun, M.H.; Tjerneld, F.; Jørgensen, H. (2007). Use of Surface Active Additives in Enzymatic Hydrolysis of Wheat Straw Lignocellulose. Enzyme and Microbial Technology, Vol. 40, pp. 888-895, ISSN 0141-0229.

Kuhad, R.C.; Singh, A. \& Eriksson, K.E. (1997). Microorganisms and Enzymes Involved in the Degradation of Plant Fiber Cell Walls. Advances in Biochemical Engineering Biotechnology, Vol. 57(Biotechnology in the Pulp and Paper Industry ), pp. 45-125, ISSN 1616-8542.

Kumar, K.B.; Balakrishnan, H.; Rele, M.V. (2004). Compatibility of Alkaline Xylanases from an Alkaliphilic Bacillus NCL (87-6-10) With Commercial Detergents and Proteases. Journal of Industrial Microbiology and Biotechnology., V. 31, P. 83-87, ISSN 1367-5435.

Kumar, P.; Barrett, D.M.; Delwiche, M.J.; Stroeve, P. (2009). Methods for Pretreatment of Lignocellulosic Biomass for Efficient Hydrolysis and Biofuel Production. Industrial and Engineering Chemistry Research, Vol. 48, pp. 3713-3729, ISSN 0888-5885.

Lakshmia, S.; Rao, C.S.; Rao, R.S.; Hobbsb, P.J.; Prakashama, R.S. (2009). Enhanced Production of Xylanase by a Newly Isolated Aspergillus terreus Under Solid State Fermentation Using Palm Industrial Waste: A Statistical Optimization. Biochemical Engineering Journal, Vol. 48, pp. 51-57, ISSN: 1369-703X.

Lamed, R.; Setter, E.; Kenig, R.; Bayer, E.A. (1983). The Cellulosome: A Discrete Cell Surface Organelle of Clostridium thermocellum Which Exhibits Separate Antigenic, CelluloseBinding and Various Cellulolytic Activities. Biotechnology and Bioengineering, Vol. 13, pp. 63-181, ISSN 0006-3592.

Lechner, B.E.; Papinutti, V.L. (2006). Production of Lignocellulosic Enzymes During Growth and Fruiting of the Edible Fungus Lentinu tigrinus on Wheat Straw. Process Biochemistry, Vol. 41, pp. 594-598, ISSN 359-5113.

Lee, D.; Yu, A.H.C.; Saddler, J.N. 1(995). Evaluation of Cellulase Recycling Strategies for the Hydrolysis of Lignocellulosic Substrates. Biotechnology and Bioengineering, Vol. 45, pp. 328-336, ISSN 0006-3592.

Leite, R.S.R.; Alves-Prado, H.F.; Cabral, H.; Pagnocca, F.C.; Gomes, E.; Da-Silva, R. (2008). Production and Characteristics Comparison of Crude $\beta$-Glucosidases Produced by Microorganisms Thermoascus aurantiacus and Aureobasidium pullulans in Agricultural Wastes. Enzyme and Microbial Technology, Vol. 43, pp. 391-395, ISSN 0141-0229.

Leonowicz, A.; Matuszewska, A.; Luterek, J.; Ziegenhagen, D.; Wojtas-Wasilewska, M.; Cho, N.S.; Hofrichter, M.; Rogalski, J. (1999). Biodegradation of Lignin by White Rot Fungi. Fungal Genetics and Biology, Vol. 27, pp. 175-185, ISSN: 1087-1845.

Li, X.L.; Chen, H.; Ljungdahl, L.G. (1997). Two Cellulases, CelA and CelC, from the Polycentric Anaerobic Fungus Orpinomyces Strain PC-2 Contain N-Terminal Docking Domains for a Cellulase-Hemicellulase Complex. Applied and Environmental Microbiology, Vol. 63, pp. 4721-4728, ISSN 0099-2240.

Lora, B.A.; Monteiro, M.B.; Assunção, V. \& Frigerio R. (2006). Levantamento Georreferenciado da Expansão da Cultura de Cana-De-Açúcar no Estado de São Paulo (Georeferenced Assessment Of Sugarcane Culture Expansion in São Paulo State), São Paulo, December 2006.

Lu, Y.; Yang, B.; Gregg, D.; Saddler, J.N.; Mansfield, S.D. (2002). Cellulase Adsorption and an Evaluation of Enzyme Recycle During Hydrolysis of Steam-Exploded Softwood Residues. Applied Biochemistry and Biotechnology, Vol. 98, pp. 641-654, ISSN: 02732289 . 
Lynd, L.R. (1996). Overview and Evaluation of Fuel Ethanol from Cellulosic Biomass: Technology, Economics, the Environment, and Policy. Annual Review of Energy and the Environment, Vol. 21, pp. 403-465, ISSN 1056-3466.

Lynd, L.R.; Weimer, P.J.; van Zyl, W.H.; Pretorius, I.S.; (2002). Microbial Cellulose Utilization: Fundamentals and Biotechnology. Microbiology and Molecular Biology Reviews, Vol. 66, No.3, pp. 506-577, ISSN 1092-2172.

Macedo, I. (2005). A Energia da Cana-de-açúcar (Sugar Cane's Energy: Twelve Studies On Brazilian Sugar Cane Agribusiness And Its Sustainability). Unica (São Paulo Sugarcane Agro Industry Union). São Paulo, Brazil. 2005.

Mackie, K.L.; Brownell, H.H.; West, K.L. \& Saddler, J.N. (1985). Effect of Sulphur Dioxide And Sulphuric Acid On Steam Explosion Of Aspenwood. Journal of Wood Chemistry and Technology, Vol.5, No.3, (April 1985), pp. 405-425, ISSN 1532-2319.

Madhu, K.M.; Beena, P.S. \& Chandrasekaran, M. (2009). Extracellular B-Glucosidase Production by a Marine Aspergillus Sydowii BTMFS 55 Under Solid State Fermentation Using Statistical Experimental Design. Biotechnology and Bioprocess Engineering, Vol.14, No.4, (August 2009), pp. 457-466, ISSN 1226-8372.

Maheshwari, R.; Bharadwaj, G.; Bath, M.K. (2000). Thermophilic Fungi: Their Physiology And Enzymes. Microbiology and Molecular Biology Reviews, Vol.64, No.3, (September 2000), pp. 461-488, ISSN 1098-5557.

Maicas, S. \& Mateo J.J. (2005). Hydrolysis of Terpenyl Glycosides in Grape Juice and other Fruit Juices: A Review. Applied Microbiology and Biotechnology, Vol.67, No.3, (May 2005), pp. 322 - 335, ISSN 1432-0614.

Maki, M.; Leung, K.T. \& Qin, W. (2009). The Prospects of Cellulase-Producing Bacteria for the Bioconversion of Lignocellulosic Biomass. International Journal of Biological Sciences, Vol.29, No.5, (July 2009), pp. 500-516, ISSN 1449-2288.

Malherbe, S. \& Cloete, T.E. (2002). Lignocellulose Biodegradation: Fundamentals and Applications. Reviews in Environmental Science and Biotechnology, Vol.1, No.2, (June 2002), pp. 105-114, ISSN 1572-9826.

Martín, C.; Klinke, H.B. \& Thomsen, A.B. (2007). Wet Oxidation as a Pretreatment Method for Enhancing the Enzymatic Convertibility of Sugarcane Bagasse. Enzyme and Microbial Technology, Vol.40, No.3, (February 2007), pp. 426-432, ISSN 0141-0229.

Martín, C.; Marcet, M.; Almazán, O. \& Jönsson, L.J. (2007a). Adaptation of a Recombinant Xylose-Utilizing Saccharomyces cerevisiae Strain to a Sugarcane Bagasse Hydrolysate With High Content of Fermentation Inhibitors. Bioresource Technology, Vol.98, No.9, (July 2007), pp. 1767-1773, ISSN 0960-8524.

Martínez, A.T.; Rencoret, J.; Marques, G.; Gutiérrez, A.; Ibarra, D.; Jiménez-Barbero, J. \& del Río, J.C. (2008). Monolignol acylation and Lignin Structure in Some Nonwoody Plants: a 2D NMR Study. Phytochemistry, Vol.69, No.16, (November 2008), pp. 28312843, ISSN: 0031-9422.

Martınez, A.T.; Ruiz-Dueñas, F.J.; Martínez, M.J; Del Río, J.C. \& Gutiérrez, A. (2009). Enzymatic Delignification of Plant Cell Wall: From Nature to Mill. Current Opinion in Biotechnology, Vol.20, No.3, (June 2009), pp. 348-357, ISSN: 0958-1669.

Mayer, A.M. \& Staples, R.C. (2002). Laccase: New Functions for an Old Enzyme. Phytochemistry, Vol.60, No.6, (July 2002), pp. 551-565, ISSN:0031-9422. 
McMillan, J.D. (1994). Pretreatment of Lignocellulosic Biomass, In: Enzymatic Conversion of Biomass for Fuels Production, Himmel, M.E.; Baker, J.O. \& Overend, R.P. pp. 292-324, American Chemical Society, ISBN 9780841229563, Washington, Dc.

Merino, S.T. \& Cherry, J. (2007). Progress and Challenges in Enzyme Development for Biomass Utilization. Advances in Biochemical Engineering Biotechnology, Vol. 108 (Biofuels), (August 2007), pp. 95-120, ISSN: 0724-6145.

Mes-Hartree, M.; Dale, B.E. \& Craig, W.K. (1988)Comparison of Steam and Ammonia Pretreatment for Enzymatic Hydrolysis of Cellulose. Applied Microbiology and Biotechnology, Vol.29, No.5, (November 1988), pp. 462-468, ISSN 1432-0614.

Mester, T.; Jong, E. \& Field, J. A. (1995). Manganese Regulation of Veratryl Alchol in White Rot Fungi and its Indirect Effect on Lignin Peroxidase. Applied and Environmental Microbiology, Vol.61, No.5, p. 1881-1887, ISSN:0099-2240..

Meyer, A.S.; Rosgaard, L. \& Sørensen, H.R. (2009). The Minimal Enzyme Cocktail Concept for Biomass Processing. Journal of Cereal Science, Vol. 50, No.3, (November 2009), pp. 337-344, ISSN 0733-5210.

Mishra, A. \& Kumar, S. (2007). Cyanobacterial Biomass as N-supplement to Agro-waste for Hyper-production of Laccase from Pleurotus ostreatus in Solid State Fermentation. Process Biochemistry, Vol.42, No.4, (April 2007), pp. 681-685, ISSN:1359-5113.

Mitchell, D.A.; Krieger, N.; Stuart, D.M. \& Pandey, A. (2000), New Developments in SolidState Fermentation. II. Rational Approaches for Bioreactor Design and Operation, Process Biochemistry, Vol.35, No.10, (July 2000), pp. 1211-1225, ISSN 0032-9592.

Moniruzzaman, M. (1996). Effect of Steam Explosion on the Physicochemical Properties and Enzymatic Saccharification of Rice Straw. Applied Biochemistry and Biotechnology, Vol.59, pp. 283-97, ISSN:0273-2289.

Montgomery, R.; Smith, F. \& Srivastava, H.C. (1956). Structure of Cornhull Hemicellulose. I. Partial Hydrolysis and Identification of 2-0- $\beta$-D-Glucopyranosyluronic Acid-DXylopyranose. Journal of American Chemistry Society., Vol.78, No.12, (June 1956), pp. 2837-2839, ISSN 1520-5126.

Mooney, C.A.; Mansfield, S.D.; Touhy, M.G. \& Saddler, J.N. (1998). The Effect of Initial Pore Volume and Lignin Content on the Enzymic Hydrolysis of Softwoods. Bioresource Technology, Vol.64, No.2, (May 1998), pp. 113-119, ISSN 0960-8524.

Mores, W.D.; Knutsen, J.S. \& Davis, R.H. (2001). Cellulase Recovery Via Membranefiltration. Applied Biochemistry and Biotechnology, Vol. 91-93, No.1, (March 2001), pp. 297-309, ISSN 0273-2289.

Morjanoff, P.J. \& Gray, P.P. (1987). Optimization of Steam Explosion as Method for Increasing Susceptibility of Sugarcane Bagasse to Enzymatic Saccharification. Biotechnology and Bioenergy Vol.29, No.6, (April 1987), pp. 733-741, ISSN 1097-0290

Mosier, N., Hendrickson, R., Ho, N., Sedlak, M. \& Ladisch, M.R. (2005). Optimization of pH Controlled Liquid Hot Water Pretreatment of Corn Stover. Bioresource Technology Vol.96, No.18, (December 2005), pp. 1986-1993, ISSN 0960-8524.

Mtui, G.Y.S. (2009). Recent Advances in Pretreatment of Lignocellulosic Wastes and Production of Value Added Products. African Journal of Biotechnology Vol.8, No.8, (April 2009), pp. 1398-1415, ISSN 1684-5315.

Nampoothiri, K.M. \& Pandey, A. (1996). Solid State Fermentation for L-Glutamic Acid Production Using Brevibacterium sp. Biotechnology Letters, Vol.18, No.2, (February 1996), pp. 199-204, ISSN 1573-6776. 
Navarro, A.R. (1994). Effects of Furfural on Ethanol Fermentation by Saccharomyces cerevisiae: Mathematical Models. Current Microbiology, Vol.29, No.2, (August 1994), pp. 87-90, ISSN1432-0991.

Nelson, D.L. \& Cox, M.M. (Eds). (2006). Lehninger - Princípios de Bioquímica. Sarvier, ISBN: 8573781661.

Nordon, R.E.; Craig, S.J. \& Foong, F.C. (2009), Molecular Engineering of the Cellulosome Complex for Affinity and Bioenergy Applications. Biotechnology Letters, Vol.31, No.4, (April 2009), pp. 465-476, ISSN 1573-6776.

Northcote, D.H. (1972). Chemistry of the Plant Cell Wall. Annual Reviews of Plant Physiology, Vol. 23, No.1, (June 1972), pp. 113-132, ISSN 0066-4294.

Nunn, J.R.; Parolis, H. \& Russel, I. (1973). Polysaccharides of the Red Algae Chaetangium erinaceum. Part I: Isolation and Characterization of the Water-Soluble Xylan. Carbohydrate Research, Vol.26, No.1, (January 1973), pp. 169-180, ISSN 0008-6215.

Olofsson, K.; Bertilsson, M. \& Lidén, G. (2008). A Short Review on SSF - an Interesting Process Option for Ethanol Production from Lignocellulosic Feedstocks. Biotechnology for Biofuels. Vol.1, No.1, (May 2008), pp. 1-7, ISSN 1754-6834.

O'neill, M.A.; York, W.S. (2003). The Composition and Structure of Plant Primary Cell Walls. In: Plant Cell Wall, Vol. 8. Annual Plant Reviews, Rose, J.K.C., pp. 1-54. ISBN: 9781841273280.

Ooshima, H.; Ishitani, Y. \& Harano, Y. (1985). Simultaneous Saccharification and Fermentation of Cellulose: Effect of Ethanol on Enzymic Saccharification of Cellulose. Biotechnology and Bioengineering, Vol.27, No.4, (April 1985), pp. 389-397, ISSN 0006-3592.

Orozco, A.L.; Pérez, M.I.; Guevara, O.; Rodríguez, J.; Hernández, M.; González-Vila, F.J.; Polvillo, O. \& Arias, M.E.J. (2008). Biotechnological Enhancement of Coffee Pulp Residues by Solid-State Fermentation with Streptomyces. Py-GC/MS Analysis. Journal of Analytical and Applied Pyrolysis, Vol.81, No.2, (March 2008), pp. 247-252, ISSN 0165-2370.

Otter, D.E.; Munro, P.A.; Scott, G.K. \& Geddes, R. (1989). Desorption of Trichoderma reesei Cellulase from Cellulose by a Range of Desorbents. Biotechnology and Bioengineering, Vol.34, No.3, (July 1989), pp. 291-298, ISSN 0006-3592.

Pal, M.; Calvo, A. M.; Terron, M. C. \& Gonzalez, A. E. (1995). Solid-State Fermentation of Sugarcane Bagasse with Flammulina velutipes and Trametes versicolor. World Journal of Microbiology and Biotechnology, Vol. 11, No.5, pp. 541-545, ISSN:0959-3993.

Palmqvist, E. \& Hahn-Hagerdal, B. (2000). Fermentation of Lignocellulosic Hydrolysates. I: Inhibition and Detoxification. Bioresource Technology, Vol.74, No.1, (August 2000), pp. 17-24, ISSN 0960-8524.

Palmqvist, E.; Almeida, J.S. \& Hahn-Hagerdal, B. (1999b). Influence of Furfural on Anaerobic Glycolytic Kinetics of Saccharomyces Cerevisiae in Batch Culture. Biotechnology and Bioengineering, Vol.62, No.4, (February 1999), pp. 447-454, ISSN 0006-3592.

Palmqvist, E.; Grage, H.; Meinander, N.Q. \& Hahn-Hagerdal, B. (1999a). Main and Interaction Effects of Acetic Acid, Furfural, and P-Hydroxybenzoic Acid on Growth and Ethanol Productivity of Yeasts. Biotechnology and Bioengineering, Vol.63, No.1, (April 1999), pp. 46-55, ISSN 0006-3592. 
Palonen H.; Tjerneld, F.; Zacchi, G. \& Tenkanen, M. (2004). Adsorption of Trichoderma reesei $\mathrm{CBH}$ I and EG II and their Catalytic Domains on Steam Pretreated Softwood and Isolated Lignin. Journal of Biotechnology, Vol.107, No.1, (January 2004), pp. 65-72, ISSN 0168-1656.

Pampulha, M.E. \& Loureiro-Dias, M.C. (1989). Combined Effect of Acetic Acid, pH and Ethanol on Intracellular $\mathrm{pH}$ of Fermenting Yeast. Appllied Microbiology and Biotechnology, Vol. 31, No. 5-6, (October 1989), pp. 547-550, ISSN 1432-0614.

Panagiotou, G., Kekos, D., Macris, B.J. \& Christakopoulos, P. (2003). Production of Cellulolytic and Xylanolytic Enzymes by Fusarium oxysporum Grown on Corn Stover in Solid State Fermentation. Industrial Crops and Products, Vol.18, No.1, (July 2003), pp. 37-45, ISSN 0926-6690.

Pandey, A. (2003). Solid-State Fermentation. Biochemistry Engeneering Journal, Vol.13, No.2-3, (March 2003), pp. 81-84, ISSN 1369-703X.

Pandey, A.; Soccol, C.R. \& Mitchell, D. (2000). New Developments in Solid State Fermentation: I- Bioprocesses and Products. Process Biochemistry, Vol.35, No.10, (July 2000), pp. 1153- 1169, ISSN 1359-5113.

Papinutti, V.L. \&Forchiassin, F. (2007). Lignocellulolytic Enzymes from Fomes sclerodermus Growing in Solid-State Fermentation. Journal of Food Engineering, Vol.81, No.1, (July 2007), pp. 54-59, ISSN 0260-8774.

Pointing, S. B. (2001). Feasibility of Bioremediation by White-rot Fungi. Applied Microbiology and Biotechnology, Vol.57, No1-2, p. 20-33, ISSN:0175-7598.

Prade, R. A. (1996). Xylanases: From Biology to Biotechnology. Biotechnology and Genetic Engeering Reviews, Vol. 13, pp. 101-131, ISSN 0264-8725.

Pradeep, V. \& Datta, M. (2002). Production of Ligninolytic Enzymes for Decolorization by Cocultivation of White-Rot Fungi Pleurotus ostreatus and Phanerochaete chrysosporium Under Solid-State Fermentation. Applied Biochemistry and Biotechnology, Vol.102-103, No.1-6, (July 2002), pp. 109-118, ISSN 1559-0291.

Prasad, S.; Singh, A. \& Joshi, H. C. (2007). Ethanol as an Alternative Fuel from Agricultural, Industrial and Urban Residues. Resources, Conservation and Recycling, Vol.50, No.1, (March 2007), pp .1-39, ISSN 0921-3449.

Qi, B.; Chen, X.; Su, Y. \& Wan, Y. (2011) Enzyme Adsorption and Recycling During Hydrolysis of Wheat Straw Lignocellulose. Bioresource Technology, Vol.102, No.3, (February 2011), pp. 2881-2889, ISSN 0960-8524.

Ragauskas, A.J.; Williams, C.K.; Davison, B.H.; Britovsek, G.; Cairney, J.; Eckert, C.A.; Frederick, W.J.; Hallett, J.P.; Leak, D.J.; Liotta, C.L.; Mielenz, J.R.; Murphy, R.; Templer, R. \& Tschaplinski, T. (2006). The Path Forward for Biofuels and Biomaterials. Science, Vol.311, No.5760, (January 2006), pp. 484-489, ISSN 1095-9203.

Ralph, J.; Lundquist, K.; Brunow, G.; Lu, F.; Kim, H.; Schatz, P.F.; Marita, J.M.; Hatfield, R.D.; Ralph, S.A.; Christensen, J.H. \& Boerjan, W. (2004). Lignins: Natural Polymers From Oxidative Coupling Of 4-Hydroxyphenylpropanoids. Phytochemistry Reviews, Vol, 3, No. 1-2, (January 2004), pp. 29-60, ISSN 1568-7767.

Reddy, G.V.; Ravindra Babu, P.; Komaraiah, P.; Roy, K.R.R.M. \& Kothari, I.L. (2003). Utilization of Banana Waste for the Production of Lignolytic and Cellulolytic Enzymes by Solid Substrate Fermentation Using Two Pleurotus Species (P. Ostreatus and P. Sajor-Caju). Process Biochemistry, Vol.38, No.10, (May 2003), pp. 1457-1462, ISSN 1359-5113. 
Rocky-Salimi, K. \& Hamidi-Esfahani, Z. (2010). Evaluation of the Effect of Particle Size, Aeration Rate and Harvest Time on the Production of Cellulase by Trichoderma reesei QM9414 Using Response Surface Methodology. Food And Bioproducts Processing, Vol.88, No.1, (March 2010), pp. 61-66. ISSN 1744-3571.

Rodríguez, J. \& Durán, N. (1988). Some New Aspects of Enzymatic Lignin Biodegradation. Brazilian Journal of Medical and Biological Research, Vol.21, No.3, (March 1988), pp. 411-422, ISSN 1678-4510.

Ruiz-Dueñas, F.J. \& Martínez, A.T. (2009). Microbial Degradation of Lignin: How a Bulky Recalcitrant Polymer is Efficiently Recycled in Nature and How We Can Take Advantage of this. Microbial Biotechnology, Vol.2, No.2, (March 2009), pp. 164-177, ISSN 1751-7915.

Saloheimo, M., Et Al. (2002). Swollenin, a Trichoderma reesei Protein with Sequence Similarity to the Plant Expansins, Exhibits Disruption Activity on Cellulosic Materials. European Journal of Biochemistry, Vol.269, No.17, (September 2002), pp. 4202 4211, ISSN 1432-1033.

Samuelsen, A.B.; Lund, I.; Djahromi, J.M.; Paulsen, B. S.; Wold, J.K. \& Knutsen, S.H. (1999). Structural Features and Anti-Complementary Activity of Some Heteroxylan Polysaccharide Fractions from the Seeds of Plantago Major L. Carbohydrate Polymers, Vol.38, No 2,(Ffebruary 1999), pp. 133-143, ISSN 0144-8617.

Sanchéz, C. (2009). Lignocellulosic Residues: Biodegradation and Bioconversion by Fungi. Biotechnology Advances, Vol.27, No.2, (March-april 2009), pp. 185-194, ISSN 07349750 .

Sandgren, M. \& Hiberg, J. S. (2005). Structural and Biochemical Studies of GH Family 12 Cellulases: Improved Thermal Stability and Ligand Complexes. Progress in Biophysics and Molecular Biology, Vol. 89, No.3, (November 2005), p. 246-291, 2005. ISSN:0079-6107.

Sandgren, M.; Stahlberg, J. \& Mitchinson, C. (2005). Structural and Biochemical Studies of GH Family 12 Cellulases: Improved Thermal Stability, and Ligand Complexes. Progress in Biophysics and Molecular Biology, Vol.89, No.3, (November 2005), pp. 246291, ISSN 0079-6107.

Sandhu, J.S.; Hudson, G.J. \& Kennedy, J.F. (1981). The Gel Nature and Structure of the Carbohydrate of Ispaghula husk ex Plantago ovata Forsk. Carbohydrate Research, Vol.93, No.2, (July 1981), pp. 247-59, ISSN 0008-6215.

Santos, M.M.; Rosa, A.S.; Dal'boit, S.; Mitchell, D.A. \& Kriger, N. Thermal Denaturation: Is Solid-State Fermentation Really a Good Technology for the Production of Enzymes? Bioresource Technology, Vol.93, No.3, (July 2004), pp. 261- 268, ISSN 09608524.

Scheller, H.V. \& Ulvskov, P. (2010). Hemicelluloses. Annual Review of Plant Biology, Vol.61, (June 2010), pp. 263-89, ISSN 1543-5008.

Schulze, E. (1891). Information Regarding Chemical Composition of Plant Cell Membrane. Berichte der Deutschen Chemischen Gesellschaft,Vol.24, pp. 2277-2287, ISSN 0009-2940

Selig, M.J.; Knoshaug, E.P.; Adney, W.S.; Himmel, M.E. \& Decker, S.R. (2008). Synergistic Enhancement of Cellobiohydrolase Performance on Pretreated Corn Stover by Addition of Xylanase and Esterase Activities. Bioresource Technology , Vol.99, No.11, (July 2008), pp. 4997-5005, ISSN 0960-8524. 
Shoham, Y.; Lamed, R. \& Bayer, E.A. The Cellulosome Concept as an Efficient Microbial Strategy for the Degradation of Insoluble Polysaccharides. Trends in Microbiology, Vol.7, No.7, (July 1999), pp. 275-281, ISSN 0966-842X.

Singh, A.; Kumar, P.K.R. \& Schügerl, K. (1991). Adsorption and Reuse of Cellulases During Saccharifi Cation of Cellulosic Materials. Journal of Biotechnology, Vol.19, No.3, (May 1991), pp. 205-212, ISSN 0168-1656.

Singh, S.; Tyagi, C.H.; Dutt, D. \& Upadhyaya, J.S. (2009). Production of High Level of Cellulase-Poor Xylanases by Wild Strains of White-Rot Fungus Coprinellus Disseminatus in Solid-State Fermentation. New Biotechnology, Vol. 26, No.3-4, (October 2009), pp.165-170, ISSN 1871-6784

Soccol, C.R.; Vandenberghe, L.P.S.; Medeiros, A.B.P.; Karp, S.G.; Buckeridge, M.; Ramos, L.P.; Pitarelo, A.P.; Ferreira-Leitão, V.; Gottschalk, L.M.F.; Ferrara, M.A.; Bom, E.P.S.; Moraes, L.M.P.; Araújo, J.A. \& Torres, F.A.G. (2010). Bioethanol from Lignocelluloses: Status and Perspectives in Brazil. Bioresource Technology, Vol.101, No.13, (Jjuly 2010), pp. 4820-4825, ISSN 0960-8524.

Somerville, C.; Bauer, S.; Brininstool, G.; Facette, M.; Hamann, T.; Milne, J.; Osborne, E.; Paredez, A.; Person, S.; Raab, T.; Vormerk, S. \& Youngs, H. (2004). Towards a System Approach to Understanding Plant Cell Walls. Science, Vol.306, No.5705, pp. 2206-2211, ISSN 0036-8075.

Statistical Yearbook AgriEnergy (2009). Ministry Of Agriculture, Livestock And Food Supply. Secretariat Of Production And Agrienergy. Available from http://www.agricultura.gov.br/arq_editor/file/Desenvolvimento_Sustentavel/A groenergia/estatisticas/anuario_cana_ingles.pdf.

Stephen, A. M. (1983). Other plant polysaccharides. In: The Polysaccharides. Aspinall, G. O., pp. 98-193, Academic, New York.

Subramaniyan, S. \& Prema, P. (2002). Biotechnology of Microbial Xylanases: Enzymology, Molecular Biology and Application. Critical Reviews in Biotechnology, Vol.22, pp. 3364, ISSN 0738-8551.

Sun, Y. \& Cheng, J. (2002). Hydrolysis of Lignocellulosic Materials for Ethanol Production: a Review. Bioresource Technology, Vol.83, pp. 1-11, ISSN 0960-8524.

Sunna, A. \& Antranikian, G. (1997). Xylanolytic Enzymes from Fungi and Bacteria. Critical Reviews in Biotechnology, Vol.17, No.1, pp. 39-67, ISSN 0738-8551.

Sutcliffe, R. \& Saddler, J.N. (1986). The Role of Lignin in the Adsorption of Cellulases During Enzymic Treatment of Lignocellulosic Material. Biotechnology And Bioengineering Symposium (Symp. Biotechnol. Fuels Chem., 8th, 1986), pp. 749-762.

Suurnäkki, A.; Tenkanen, M.; Siika-Aho, M.; Niku-Paavola, M.L.; Viikari, L. \& Buchert, J. (2000). Trichoderma Reesei Cellulases and their Core Domains in the Hydrolysis and Modification of Chemical Pulp. Cellulose, Vol.7, pp. 189-209, ISSN 0969-0239.

Taherzadeh, M.J. \& Karimi, K. (2007). Enzyme-Based Hydrolysis Process for Ethanol from Lignocellulosic Materials: a Review. BioResources, Vol.2, No.4, pp. 707-738, ISSN 0960-8524.

Taherzadeh, M.J.; Gustafsson, L.; Niklasson, C. \& Liden, G., (1998). Conversion of Furfural in Aerobic and Anaerobic Batch Fermentation of Glucose by Saccharomyces cerevisiae. Journal of Bioscience and Bioengeneering, Vol.87, pp.169-174, ISSN 13891723. 
Talebnia, F.; Karakashev, D. \& Angelidaki, I. (2010). Production of Bioethanol from Wheat Straw: an Overview on Pretreatment, Hydrolysis and Fermentation. Bioresource Technology, Vol.101, pp. 4744-4753, ISSN 0960-8524.

Teixeira, F.A.; Pires, A.V. \& Nunes, P.V. (2007). Sugarcane Pulp in the Feeding of Bovine. Revista Electronica de Veterinaria, Vol.8, pp. 1-9, ISSN 1695-7504.

Tengborg, C.; Galbe, M. \& Zacchi, G. (2001). Reduced Inhibition of Enzymatic Hydrolysis of Steam-Pretreated Softwood. Enzyme and Microbial Technology, Vol.28, pp. 835-844, ISSN 0141-0229.

Tengerdy, R.P. \& Szakacs, G. (2003). Bioconversion of Lignocellulose in Solid Substrate Fermentation. Biochemistry and Engeneering Journal, Vol.13, pp. 169-179, ISSN 1369703X.

Timell, T.E. (1967). Recent Progress in the Chemistry of Wood Hemicelluloses. Wood Science Technology, Vol.1, pp. 45-70, ISSN 0043-7719.

Timell, T.E., (1965). Wood Hemicelluloses. Advances in Carbohydrate Chemistry and Biochemistry, Vol.20, pp. 409-483, ISSN 0065-2318.

Torres, E.; Bustos-Jaimes, I. \& Le Borgne, S. (2003). Potencial Use of Oxidative Enzymes for the Detoxification of Organic Pollutants. Applied Catalysis Environmental, Vol.46, pp. 1-15, ISSN 0926-3373.

Tu, M.; Chandra, R.P. \& Saddler, J.N. (2007). Evaluating the Distribution of Cellulases and the Recycling of Free Cellulases During the Hydrolysis of Lignocellulosic Substrates. Biotechnology Progress, Vol.23, pp. 398-406, ISSN 8756-7938.

Uffen, R.L. (1997). Xylan Degradation: a Glimpse at Microbial Diversity. Journal of Industrial. Microbiology and Biotechnology, Vol.19, pp. 1-6, ISSN 1367-5435.

Vares, T.; Kalsi, M. \& Hatakka, A. (1995). Lignin Peroxidases, Manganese Peroxidases, and Other Ligninolytic Enzymes Produced by Plebia Radiata During Solid-State Fermentation of Wheat Straw. Applied and Environmental Microbiology, Vol.61, pp. 3515-3520, ISSN 0099-2240.

Varga, E.; Reczey, K. \& Zacchi, G. (2004). Optimization of Steam Pretreatment of Corn Stover to Enhance Enzymatic Digestibility. Applied Biochemistry and Biotechnology., Vol.113-116, pp. 509-523, ISSN 0273-2289.

Verduyn, C.; Postma, E.; Scheffers, W.A. \& Van Dijken, J.P. (1990). Energetics of Saccharomyces Cerevisiae in Anaerobic Glucose-Limited Chemostat Cultures. Journal of General Microbiology. Vol.136, pp. 405-412, ISSN 0022-1287.

Viesturs, U.F.; Aspite, A.F.; Laukevies, J.J.; Ose, V.P. \& Bekers, M.J. (1981). Solid State Fermentation of Wheat Straw with Chaeromium cellulolyticum and Trichoderma lignorum. Biotechnolology and Bioengeneering Symposium., Vol.11, pp. 359-369, ISSN 0572-6565.

Viniegra-Gonzalez, G.; Favela-Torres, E.; Noe Aguilar, C.; Jesus Romero-Gomez, J.; DiazGodinez, G. \& Augur, C. (2003). Advantages of Fungal Enzyme Production in Solid State over Liquid Fermentation Systems. Biochemical and Engeneering Journal., Vol.13, pp. 157-167, ISSN 1369-703X.

Wang, M.; Wang, J. \& Tan, J.X. (2011). Lignocellulosic Bioethanol: Status and Prospects. Energy Sources, Part A, Vol. 33, pp. 612-619, ISSN 1556-7036

Weigert, B.; Klein, K.; Rizzi, M.; Lauterbach, C. \& Dellweg, H. (1988). Influence of Furfural on the Aerobic Growth of the Yeast Pichia Stipitis. Biotechnology Letters, Vol.10, No. 12, pp.895-900, ISSN 0141-5492. 
Westbye, P.; Kohnke, T.; Glasser, W. \& Gatenholm, P. (2007). The Influence of Lignin on the Selfassembly Behavior of Xylan Rich Fractions from Birch. Cellulose, Vol.14, pp. 603613, ISSN 0969-0239.

Whitney, S. E.C.; Gidley, M.J. \& Mcqueen-Mason, S.J. (2000). Probing Expansin Action Using Cellulose/Hemicellulose Composites. Plant Journal, Vol.22, No. 4, pp. 327-334, ISSN 0960-7412.

Wilkie, K.C.B. (1979). The Hemicelluloses of Grasses and Cereals. Adv. CarbohydrateChemistry and Biochemistry, Vol.36, pp. 215-264, ISSN 0065-2318.

Wong, D. (2006). Feruloyl Esterase. Applied Biochemistry and Biotechnology, Vol.133, pp. 87112, ISSN 0273-2289.

Wong, D.W.S. (2009). Structure and Action Mechanism of Ligninolytic Enzymes. Applied Biochemistry and Biotechnology, Vol.157, pp. 174-209, ISSN 0273-2289.

Wong, K.K.Y.; Tan, L.U.L. \& Saddler, J.N. (1988). Multiplicity of $\beta-1,4$ Xylanases in Microorganisms: Functions and Applications. Microbiological Reviews, Vol.52, pp. 305-317, ISSN: 0146-0749.

Xiang, Q.; Lee, Y.Y.; Pettersson, P.O. \& Torget, R.W. (2003). Heterogeneous Aspects of Acid Hydrolysis of *A-Cellulose. Applied Biochemistry and Biotechnology, Vol.105-108, pp. 505- 514, ISSN 0273-2289.

Xiao, Z.Z.; Zhang, X.; Gregg, D.J. \& Saddler, J.N. (2004). Effects of Sugar Inhibition on Cellulases and Beta-Glucosidase During Enzymatic Hydrolysis of Softwood Substrates. Applied Biochemistry and Biotechnology, Vol. 113-16, pp. 1115-1126, ISSN 0273-2289

Xin, F. \& Geng, A. (2011). Utilization of Horticultural Waste for Laccase Production by Trametes Versicolor Under Solid-State Fermentation. Applied Biochemistry and Biotechnology, Vol. 163, No. 2, pp. 235-246, ISSN 0273-2289.

Yu, P.; Mckinnon, J.J. \& Christensen, D.A. (2005). Improving the Nutritional Value of Oat Hulls for Ruminant Animals with Pretreatment of a Multienzyme Cocktail: In Vitro Studies. Journal of Animal Science, Vol.83, pp. 1133-1141, ISSN 0021-8812.

Yun Si, J.C.S.; Chung, D.K. \& Choi, H.S. (2001). Purification and Some Properties of a BetaGlucosidase from Trichoderma harzianum Type C-4. Bioscience Biotechnology and Biochemistry., Vol. 65, pp. 2028-2032, ISSN 0916-8451. 


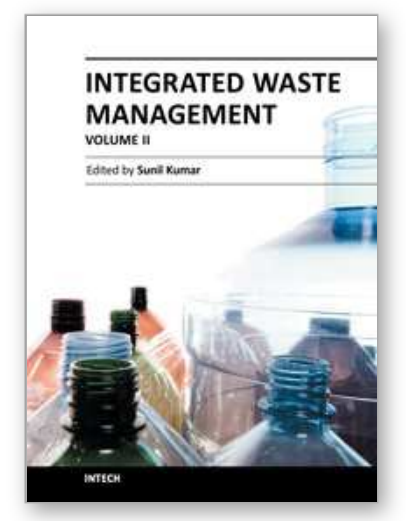

\author{
Integrated Waste Management - Volume II \\ Edited by Mr. Sunil Kumar
}

ISBN 978-953-307-447-4

Hard cover, 472 pages

Publisher InTech

Published online 23, August, 2011

Published in print edition August, 2011

This book reports mostly on institutional arrangements under policy and legal issues, composting and vermicomposting of solid waste under processing aspects, electrical and electronic waste under industrial waste category, application of GIS and LCA in waste management, and there are also several research papers relating to $\mathrm{GHG}$ emission from dumpsites.

\title{
How to reference
}

In order to correctly reference this scholarly work, feel free to copy and paste the following:

Daniela Alonso Bocchini Martins, Heloiza Ferreira Alves do Prado, Rodrigo Simões Ribeiro Leite, Henrique Ferreira, Márcia Maria de Souza Moretti, Roberto da Silva and Eleni Gomes (2011). Agroindustrial Wastes as Substrates for Microbial Enzymes Production and Source of Sugar for Bioethanol Production, Integrated Waste Management - Volume II, Mr. Sunil Kumar (Ed.), ISBN: 978-953-307-447-4, InTech, Available from: http://www.intechopen.com/books/integrated-waste-management-volume-ii/agroindustrial-wastes-assubstrates-for-microbial-enzymes-production-and-source-of-sugar-for-bioetha

\section{INTECH}

open science | open minds

\section{InTech Europe}

University Campus STeP Ri

Slavka Krautzeka 83/A

51000 Rijeka, Croatia

Phone: +385 (51) 770447

Fax: +385 (51) 686166

www.intechopen.com

\section{InTech China}

Unit 405, Office Block, Hotel Equatorial Shanghai

No.65, Yan An Road (West), Shanghai, 200040, China

中国上海市延安西路 65 号上海国际贵都大饭店办公楼 405 单元

Phone: +86-21-62489820

Fax: +86-21-62489821 
(C) 2011 The Author(s). Licensee IntechOpen. This chapter is distributed under the terms of the Creative Commons Attribution-NonCommercialShareAlike-3.0 License, which permits use, distribution and reproduction for non-commercial purposes, provided the original is properly cited and derivative works building on this content are distributed under the same license. 